\title{
Geneza izbornih procesa u Bosni i Hercegovini od 1996. do 2018. godine i moguće promjene u Ustavu i Izbornom zakonu
}

\author{
Suad Arnautović \\ Prof. dr., politolog \\ Član Centralne izborne komisije Bosne i Hercegovine \\ suad.arnautovic@izbori.ba
}

Sažetak: Demokratizaciju razlikujemo od stabilne demokracije. U procesu demokratizacije koja je započela 1990. godine, Bosna i Hercegovina je prošla faze tranzicije, zamjene i premještanja autoritarnog, jednopartijskog sistema u višestranački sistem, čime su u velikoj mjeri prekinute ideje (ideologija), institucije i procedure bivšeg režima. Ipak, Bosnu i Hercegovinu još uvijek ne možemo definirati kao „stabilnu demokraciju“. Koji su uzroci ovakvog stanja?

Prošlo je 30 godina od prvih višestranačkih izbora u Bosni i Hercegovini. Bio je to početak procesa tranzicije iz jednopartijskog u višestranački politički sistem. Od tada do kraja 2018. godine održano je osam predsjedničkih izbornih ciklusa i istovremeni izbori za nacionalno zakonodavstvo. Tokom tog perioda stvorene su, ali i nestale iz političke arene, brojne političke stranke različitih ideoloških smjerova, izborne podrške i organizacijske strukture. Neke političke stranke koje su 1990. izabrane u nacionalni parlament bile su „parlamentarne stranke“ i nakon parlamentarnih izbora 2018, a mnoge su u međuvremenu nestale s političke scene.

Bosanskohercegovački izborni sistem pretrpio je nekoliko značajnih promjena tokom prijelaznog razdoblja. Sistem proporcionalne predstavljenosti (PR) za parlamentarne izbore uveden je na izborima 1990. godine. U međuvremenu su se dogodile strukturne promjene u tom sistemu, u svim glavnim elementima tog sistema: (1) u oblikovanju izbornih jedinica i njihovoj magnitudi; (2) u tipu glasačkog listića; (3) u matematičkoj formuli za preračun glasova u mandate. Također, promijenjena su neka svojstva većinskog sistema (FPTP) za predsjedničke i gradonačelničke izbore? Ove "tehničke" promjene u izbornom sistemu uz zadržavanje prevaziđenog ekskluzivnog etno-teritorijalnog političkog predstavništva izborne procese u $\mathrm{BiH}$ svode na puki elektoralizam. Ima li alternative takvom stanju?

To su osnovna pitanja na koja će se pokušati odgovoriti u ovom radu.

Ključne riječi: elektoralizam, elektoralistička zabluda, izborni sistem, stranački sistem, izborne jedinice, glasački listić, formula za preračun glasova u mandate

\section{Uvod}

Demokratski prijelaz u Bosni i Hercegovini iz autoritarnog (jednopartijskog) sistema, koji je vladao 45 godina (1945-1990) i koji je otpočeo 1990. godine, u sistem stabilne, konsolidirane liberalne demokracije još uvijek traje. Taj 
proces označavamo pojmom demokratizacije. Formalno-pravno ovaj proces je otpočeo 1990. godine održavanjem prvih višestranačkih izbora u Bosni i Hercegovini 18. novembra 1990. godine (Arnautović, 1996). To je period tzv. trećeg talasa demokratizacije u 20. stoljeću (Huntigton piše o tri talasa i dva protutalasa demokratizacije) kojega na početku karakterizira transformacija i zamjena - „transplacement” (Huntigton, 1991 : 276) u kojem se naglašava snažna uloga opozicije vladajućem režimu, u slučaju BiH Savezu komunista $\mathrm{BiH}$, i istovremenoj prilagođavajućoj ulozi stranke toga starog režima novim uvjetima, u slučaju BiH transformacija SKBiH u SKBiH-SDP. Dakle, taj proces pluralizacije bosanskohercegovačke političke scene započinje tokom 1990. godine (Pejanović, 2005 : 111; 2012 : 83) kada dolazi do „cvjetanja demokracije” (Ćurak, 2006 : 107). Krešendo te „,negativne demokracije” (Ćurak, 2006 : 107) dostignut je „kroz konstituciju političkih stranaka na mononacionalnoj osnovi" (Ćurak, 2006 : 107) i on se naglo prekida oružanom agresijom na međunarodno priznatu Republiku Bosnu i Hercegovinu u periodu 1992-1995. godine. Dakle, ovaj proces možemo nazvati procesom demokratizacije što je suprotno pojmu stabilne demokracije, odnosno konsolidirane demokracije koji u slučaju Bosne i Hercegovine još uvijek nije dosegnut.

Dakle, proces demokratizacije razlikujemo od stabilne, konsolidirane demokracije, za koju R. A. Dahl smatra da je karakterizira "trajno prisutna odgovornost vlade prema zahtjevima svojih građana, koji se smatraju politički jednakim" (Dahl, 1997 : 11). U procesu demokratizacije koja je započela 1990. godine, padom socijalističkog režima, Bosna i Hercegovina je prošla faze tranzicije, zamjene i premještanja autoritarnog, jednopartijskog sistema u višestranački sistem (Huntigton), čime su u velikoj mjeri prekinute ideje (ideologija), institucije i procedure bivšeg režima. "Nakon sloma socijalističkih režima, bivše su jednopartijske države u početku 1990-ih prošle kroz višestranačke izbore i deklarirale se kao liberalnodemokratske države, ali još nisu uspostavile stabilne liberalnodemokratske institucije, pa se nazivaju novim demokracijama"” Ipak, Bosnu i Hercegovinu još uvijek ne možemo definirati kao novu „stabilnu demokraciju“. ${ }^{2}$ Koji su uzroci ovog stanja?

Ono se ogleda prije svega u nestabilnom unutarnjem i vanjskom društvenom okruženju koje smo definirali pojmom ,permanentne privremenosti (Arnautović, 2020.1 : 20). Period od disolucije SFRJ i osamostaljenja BiH

\footnotetext{
${ }^{1}$ Demokracija. Hrvatska enciklopedija, mrežno izdanje. Leksikografski zavod Miroslav Krleža, 2020. Pristupljeno 27. 1. 2021. http://www.enciklopedija.hr/Natuknica.aspx?ID=14516>.

${ }^{2} \mathrm{O}$ teorijama transformacije i uvjetima za izgradnju stabilne demokracije detaljnije vidjeti u: Merkel, Wolfgang, Teorije transformacije: demokratska konsolidacija postautoritarnih društava, Politička misao, Vol XXXVI, (1999.), br. 3, str. 121-150,
} 
bremenit je stalnim krizama. Protiv $\mathrm{BiH}$, njene samostalnosti kao suverene i nezavisne države u okviru međunarodno priznatih granica vođena je oružana agresija (1992-1995). Potom je 1995. godine uslijedio „,nepravedan” Daytonski mirovni sporazum. Međutim, osporavanje njene nezavisnosti i suverenosti nastavlja se i u postdaytonskoj fazi, pa sve do danas, a najizrazitija forma osporavanja ogleda se u stalnoj blokadi državnih institucija i izbjegavanju usvajanja sistemskih državnih zakona, te blokiranje pristupnog puta BiH Europskoj uniji i NATO alijansi. Takvo projektirano stanje smo definirali sintagmom nametnute ,permanente privremenosti (Arnautović, 2020.1 : 20).” To stanje ima za cilj da se onemogući trajna sigurnosna stabilnost države i njen ekonomski napredak. To je društveno stanje koje karakterizira kontinuirana penetracija i mješanje drugih država, posebno susjeda, u unutarnja pitanja $\mathrm{BiH}$, velika stopa organiziranog i općeg kriminaliteta, korupcije i nestabilnost budžetskih institucija. Bosna i Hercegovina se kontinuirano prikazuje kao "fragilna", "propala", "neuspjela", "nemoguća” država.

U još goroj ambijentalnosti, nakon masakra i genocida nad Bošnjacima, prihvaćen je i potpisan Daytonski mirovni sporazum koji je dizajnirao i izborni sistem ekskluzivnog etno-teritorijalnog političkog predstavljanja. Opće je poznato da je aktuelni izborni sistem u BiH diskriminatoran, ${ }^{3}$ a taj diskriminatorni karakter proizilazi iz toga modela etno-teritorijalnog političkog predstavljanja (Arnautović, 2017 : 5). Dakle, u takvom političkom sistemu, u ambijentu "ekstremnog pluralizma" (Sartori, 2002 : 248) odvijaju se diskriminatorni izborni procesi u $\mathrm{BiH}$ i u tome vidimo nestabilnu demokraciju. To stanje karakterizira veliki broj političkih stranaka i njihova raspršenost bez jasne ideološke grupiranosti u političkoj areni, ali i veliki broj elektivnih (relevantnih) tj. efektivnih političkih stranaka koje učestvuju u (sporom i neefikasnom) procesu odlučivanja.

Politički pluralizam u BiH u postdaytonskom periodu je, Sartorijevskim rječnikom kazano, esktremno "polariziran", tj. "atomiziran" čemu doprinosi veliki broj izbornih ciklusa u relativno kratkom vremenu bezkvalitetne reforme izbornog sistema (“elektoralistička zabluda”). Preuzimamo Sartorijevu klasifikaciju "ekstremnog pluralizma", odnosno "atomiziranog pluralizma" prema kriteriju broja stranaka gdje više od pet stranaka čini visoku fragmentaciju i

\footnotetext{
${ }^{3}$ Vidjeti obrazloženje presuda Europskog suda za ljudska prava u slučajevima Sejdić-Finci vs BiH; Ilijaz Pilav vs BiH; Azra Zornić vs BiH; Samir Šlaku vs BiH; Svetozar Pudarić vs BiH. Npr. Sejdić i Finci protiv Bosne i Hercegovine (Aplikacija br. 27996/06 i 34836/06) PRESUDA STRASBOURG 22. decembra 2009. U presudi Sejdić-Finci vs BiH Sud je utvrdio: "Prema tome, ograničenje ovih prava, posebno po sumnjivom osnovu kao što je rasna i etnička pripadnost su, ne samo diskriminatorska, nego i podrivaju sam smisao državljanstva."
} 
ekstremni pluralizam (Sartori, 2002 : 248-249). U BiH ekstremni pluralizam dokazujemo brojem političkih stranaka koje su se takmičile unutar političke arene u $\mathrm{BiH}$ na općim i predsjedničkim izborima od prvih postdaytonskih izbora 1996. do posljednjih, osmih po redu, općih izbora održanih 2018. godine, odnosno brojem "efektivnih političkih stranaka" koje smo mjerili prema broju osvojenih mandata i glasova u državnom parlamentu, kao i njihovom koalicijskom, odnosno ucjenjivačkom potencijalu (Sartori, 2002 : 341).

Izborne sisteme klasificiramo prema tri mjerila: (1) prema pravilima odlučivanja o izbornom pobjedniku; (2) prema načelima predstavništva; te (3) prema političkim efektima na birače, stranački sistem i strukturu parlamenta (Kasapović, 2003 : 160-161). Centralno pitanje koje se ustavnom i izbornom reformom u BiH treba riješiti jeste kakvu političku kulturu i koje načelo predstavništva u XXI stoljeću treba izgraditi i primjeniti u BiH? U odgovoru na to pitanje podsjećamo na elementarne kriterije reprezentativnosti koje bi trebalo konsultirati pri dizajniranju novog formata državnog Parlamenta $\mathrm{BiH}$.

Podsjetimo da su još 1963. godine Gabriel Almond i Sidney Verba u svom kapitalnom djelu "Građanska kultura" ustvrdili da je politička kultura varijabla koja povezuje mikro i makro politike u nekom političkom sistemu. Zato je politička kultura cjeline naroda, a ne samo elita, bitna za stabilno funkcioniranje političkog sistema. Time su ovi autori otvorili problem kongruencije i dispariteta između kulture i strukture. Njihova je teza da demokratskom političkom poretku, odgovara tip građanske, odnosno demokratske političke kulture (Vujičić, 1999 : 114). "Razvoj stabilne i efikasne demokratske vlade ovisi ne samo o strukturama države i politike: on ovisi o orijentacijama koje ljudi imaju prema političkom procesu - o političkoj kulturi. Ukoliko politička kultura nije u stanju podržati demokratski sistem, šanse za uspjeh ovog sistema su slabe" (Almond, G., Verba, S., 1963 : 498).

Izbori u BiH od 1996. do danas su samo služili (i služe) kao rituali simboličkog učešća birača u potvrđivanju egzistirajuće troetničke etno-teritorijalne autoritarne vlasti. Naime, ti izborni procesi ništa bitno nisu promijenili u prihvaćenom ekskluzivnom etno-teritorijalnom modelu političkog predstavljanja. Oni nisu pomogli u etabliranju stabilne demokracije u $\mathrm{BiH}$ niti su donijeli neophodni balans između građanskog i etno-teritorijalnog političkog predstavljanja. Na sceni je, dakle, već duži period ono stanje društvenih odnosa u političkoj sferi koje politolozi definiraju pojmom „elektoralizam”, odnosno „elektoralistička zabluda”. To je drugo ime za pogrešno uvjerenje da je održavanje formalno ,free and fair” izbora conditio sine qua non postojanja stabilne demokracije. Međunarodni faktori koji su bitno krojili našu postdaytonsku 
sudbinu su bili upravo zagovornici i slijepi sljedbenici „elektoralističke zablude", odnosno koncepcije "čestih" izbora zanemarivši njihov nedovoljan uticaj na razvoj i izgradnju stabilne demokracije u $\mathrm{BiH}$.

\section{Bosanskohercegovačka elektoralistička zabluda}

Višestranački, kompetetivni, „slobodni i pošteni” izbori („free and fair” elections) su neophodni za ostvarenje uspješne demokracije i njihovo održavanje u načelu i prividno simbolizira ostvarenje demokratske vlasti i načela slobodnih i demokratskih izbora. ${ }^{4}$ Međutim, takvi izbori, sami po sebi, su nedovoljni za postizanje toga cilja, tj. izgradnju i očuvanje uspješne i stabilne demokracije, odnosno ostvarenje demokracije kako je, primjera radi, definira Robert A. Dahl. Puko tehničko održavanje izbora koje manifestno odražavaju demokratsku kompeticiju vodi ka stanju koje su teoretičari definirali pojmom elektoralizam. ${ }^{5}$

Elektoralizam opisuje onu paradoksalnu društvenu situaciju kada tranziciju vladavine tvrdog autoritarnog sistema upravo pokreće i njome upravlja taj isti vladajući režim (incumbent). Međutim, zbog dominantnog položaja postojećeg autoritarnog režima tokom cijelog procesa tranzicije, on ne uspijeva postići institucionalne kvalitete stabilne liberalne demokracije. U „elektoralizmu” režim u osnovi provodi i prikazuje izbore kao „slobodne i poštene”, ali u takvom sistemu izostaju drugi bitni elementi demokracije, poput vladavine prava, jednakih građanskih i političkih prava i institucionalne podjele vlasti. Čitav izborni proces usmjeren je u korist očuvanja pozicije aktuelnog režima.

Karl tvrdi da ,pod izvjesnim okolnostima izbori mogu čak i ometati demokratizaciju” (Karl, 2000 : 95). ${ }^{6}$ To se naročito dešava kada izbori služe kao rituali simboličke participacije kako bi potvrdili egzistirajuću autoritarnu vlast (Sovjetski savez, Indonezija pod Suhartom); kada izbori uključuju puno prisile i pokroviteljstvo nad uskraćivanjem poštene šanse legalnim opozicionim strankama da se takmiče za vlast (Mexico prije 1994.); kada se izbori održavaju prerano s ciljem zaustavljanja liberalizacije blokiranjem pregovora (El Salvador 1982); kada izbori pogoršavaju etničke, religijske ili ostale bazične društvene rascijepe (Burundi 1993); kada se održavaju „demonstracije“

\footnotetext{
${ }^{4}$ Načela slobodnih, općih, jednakih, direktnih i tajnih izbora.

${ }^{5}$ Termin elektoralizam je prva upotrijebila Terry Lynn Karl, profesorica političkih znanosti sa Univerziteta Stanford (Karl, 1986), da bi opisala stanje društva koje je došlo na "pola puta" od autoritarne vlasti ka stabilnoj demokratskoj vladavini.

6 "Under some circumstances, elections may even impede democratization."
} 
u svrhu legitimiranja intervencije strane sile ili zahvale stranim donatorima (Vietnam 1967; Bosna 1996) (Karl, 2000 : 95).

Kao ideologija, elektoralizam, uzdiže izbore iznad svih ostalih dimenzija demokracije. U tome polazi od dvije ključne pretpostavke. Prva, pretpostavlja se da će takmičarska kampanja ili pljeva tj. "chaff” kako je naziva Robert Dahl, demokratskog uređenja proizvesti proces u kojem će se pojaviti svrsishodne političke stranke, alijanse i koalicije koje bi se takmičile i, neovisno o relativnoj snazi tih stranaka, formirale parlamentarne ili predsjedničke sisteme, oblikovale poštene izborne administracije i predstavnička zakonodavna tijela (Karl, 2000 : 95). Druga, pretpostavlja se da će neka minimalna forma "elektoralističke" demokracije biti ishod toga procesa. Mada takvi režimi još uvijek mogu biti daleko od liberalnih demokracija - utoliko što njihove vojske nisu podređene izabranim civilnim zvaničnicima, njihova izvršna vlast nije ograničena drugim nezavisnim vladinim institucijama ili građanska i politička prava nisu priznata - elektoralisti smatraju da demokratska "dobra" proizlaze iz same činjenice da su njihovi zakonodavni i izvršni uredi popunjeni putem održavanja regularnih konkurentskih izbora (Karl, 2000 : 95).

Mada, posmatrači izbora mogu neke izbore smatrati slobodnim i poštenim temeljeći to na osnovu procedura glasanja i njihovom posmatranju izbora na izborni dan (naprimjer, tajnost glasanja, pristup svim glasačkim mjestima, podesne glasačke kutije, ispravne procedure brojanja, i slično) djelotvornije mjerenje slobode i poštenja je stepen na kojem su krucijalne slobode prisutne prije izbornog dana, posebno sloboda kretanja, govora, okupljanja i udruživanja i sloboda od zastrašivanja u vezi sa izborima i izbornom kampanjom (Karl, 2000 : 96). Ako je odlika sistema da je mjesecima prije izbora jako izraženo odsustvo transparentnosti, neuspjeh u uspostavi nezavisne i nepristrasne izborne komisije, prljava izborna kampanja, pretjerano pristrasan pristup medijima ili javnim fondovima, predrasudan i štetan tretman kandidata od strane policije, armije i sudova i tako dalje, onda su perspektive loše za trajnu demokratizaciju nakon glasanja (Karl, 2000 : 96). Nadalje, ako zainteresirane stranke nisu dogovorile kako izbori trebaju biti vođeni, ko ima pravo glasa, koja vrsta izbornog sistema će se koristiti, šta čini slobodu i poštenje, koje teme su predmet demokratskog glasanja, onda izbori neće služiti u svrhu demokratizacije. Ali, ako je ovaj kontekst utemeljen na "demokratskoj pogodbi", i to na zajednički postavljenim pravilima o kojima su se svi učesnici dogovorili, tada je vjerojatnije da će proizvesti ishode koje elektoralisti pretpostavljaju (Karl, 2000 : 96). 
Šta, dakle, elektoralizam predstavlja? To je političko shvaćanje, ideologija, ali i praktična politika koja smatra da se pukim održavanjem izbora može "prenijeti, uspostaviti i učvrstiti demokracija u nedemokratskim, preddemokratskim ili poludemokratskim političkim sustavima" (Kasapović, 2003 : 79). To je vrsta izborne politike koju karakterizira provođenje čestih izbora na svim nivoima političkog sistema, a naročito izbora na nacionalnom nivou, a da prethodno nije izvršena "demokratska pogodba" i postignut sveobuhvatni društvenih ugovor o ključnim aspektima slobodnih i poštenih izbora.

U Bosni i Hercegovini je od 1996. do 2020. godine, dakle u periodu od 24 godine, održano osam parlamentarnih, osam predsjedničkih i sedam lokalnih izbornih ciklusa uz dva ciklusa vanrednih izbora u Republici Srpskoj (1997. i 2007.). Sve te izborne cikluse karakterizira diskriminirajuće izborno zakonodavstvo, posebno u pogledu ostvarivanja prava zagarantiranih Međunarodnim paktom o građanskim i političkim pravima (1966.) i Opcionim protokolima (1996. i 1989.) i Europskom konvencijom za zaštitu ljudskih prava i temeljnih sloboda. Na nacionalnom nivou još uvijek nema mjesta u Predsjedništvu BiH i Domu naroda Parlamentarne skupštine BiH za državljane BiH koji se ne izjašnjavaju kao Bošnjaci, Srbi i Hrvati. Isti je slučaj na nivou izbora predsjednika i potpredsjednika entiteta. To umnogome doprinosi da se naš izborni sistem kvalificira kao diskriminirajući. Nastavak održavanja izbornih ciklusa pod takvim uvjetima nije ništa drugo do bosanskohercegovačka elektoralistička zabluda. Puki elektoralizam.

\section{Izborni sistem i proporcionalnost}

$\mathrm{U}$ posljednje vrijeme, naročito nakon presude Ustavnog suda $\mathrm{BiH} \mathrm{u}$ predmetu U-23/14 kolokvijalno nazvanom predmet "Ljubić", unutar političke arene u Bosni i Hercegovini žestoko je nametnuta teza o potrebi promjene Izbornog zakona $\mathrm{BiH}$ kako bi se osiguralo „legitimno političko predstavljanje". ${ }^{7}$ U suštini radi se o političkom projektu održanja statusa quo u pogledu ekskluzivnog etno-teritorijalnog političkog predstavljanja definiranog u Daytonskom Ustavu BiH koji je dao ekskluzivna prava tzv. konstitutivnim narodima (Bošnjacima, Srbima i Hrvatima) u BiH, a potpuno diskriminirao građane koji im ne pripadaju ili se uopće ne izjašnjavaju u etničkom smislu nego samo kao građani BiH (npr. Azra Zornić.). Međutim, Izbornim

\footnotetext{
${ }^{7}$ Grbavac V., Pepić I., Vukoja I., Meritum i razumijevanje odluke Ustavnog suda BiH U-23-14, Institut za društveno-politička istraživanja (IDPI), Mostar. file:///C:/Users/Korisnik/Downloads/38_Vukoja_Grbavac_Pepic\%20(1).pdf, posjećeno 29.1.2021.
} 
zakonom $\mathrm{BiH}$ se ne može mijenjati Ustav $\mathrm{BiH}$, nego obrnuto. Prvo je potrebno Ustavom BiH definirati kriterije reprezentativnosti u Parlamentu BiH, a potom prema tim kriterijima usvojiti izborni sistem koji će osigurati mehanizme za izbor političkih predstavnika. Dakle, u zahtjevima za izmjene Izbornog zakona $\mathrm{BiH}$ radi osiguranja "legitimnog političkog predstavljanja" ustvari se radi o eklatantnoj zamjeni teza. Mirovnim sporazumom u Daytonu je dogovoren jedan način političke reprezentativnosti i on se ne može promijeniti „puzajućom izbornom reformom”. Potreban je novi društveni konsenzus o političkom predstavništvu što podrazumijeva izmjenu Ustava $\mathrm{BiH}$.

Zato je važno podsjetiti na elementarna načela političkog predstavništva. Osnovno demokratsko načelo, načelo jednakosti glasa, prema Dieteru Nohlenu, glasi: „Svaki glas treba da ima jednaku brojčanu vrijednost. Jednakost glasova - načelo izbornog prava koje je usko povezano sa širenjem općeg izbornog prava - postiže se onda kada na cijelome izbornom području jedinstveno na određeni udio pučanstva (ili onih s biračkim pravom, rjeđe danih valjanih glasova) otpada jedan mandat, dakle kada je primjenjen ključ jednakog predstavništva" (Nohlen, 1992 : 48). Nohlen, nadalje, ističe da "granice tolerancije u odstupanjima od propisa o jednakosti često se toliko prekoračuju da više ne može biti ni govora o jednakome izbornom pravu. Rezultat izbora tada je iz temelja izmanipuliran" (Nohlen, 1992 : 48).

Kada se primjeni načelo jednakosti ${ }^{8}$ i prema tome odredi srednja vrijednost na koju otpada jedan mandat onda postoje dvije proceduralne mogućnosti. Prva je da se dizajniraju izborne jedinice koje otprilike obuhvataju ono stanovništvo kojemu proporcionalno pripada jedan mandat. Ovaj postupak se uglavnom primjenjuje pri podjeli zemlje na uninominalne izborne jedinice, čije granice je potrebno prilagođavati u jednakim vremenskim intervalima shodno promjeni veličine stanovništva (najpoželjnije je preispitati granice izbornih jedinica svake četiri godine). Druga je da se izračuna koliko mandata proporcionalno pripada jednoj izbornoj jedinici na osnovu broja stanovnika ili udjela u stanovništvu (mjerilo veličine može biti i broj osoba s biračkim pravom). Ovaj postupak se primjenjuje kod obrazovanja plurinominalnih izbornih jedinica. Izborna magnitude se može mijenjati i prilagođavati kao posljedica migracija. Pri tome treba voditi računa o veličini izborne magnitude.

Mala izborna magnituda sputava razmah političkog pluralizma tj. višestranačkog sistema, onemogućava razvoj nezavisnih stranaka i tendira ka dvostranačju, a sistem proporcionalne reprezentacije svodi na većinski sistem. To

${ }^{8} \mathrm{O}$ ovome načelu, kao i o ostalim načelima demokratskog izbornog prava, šire vidjeti u: Arnautović, $2009: 287-293$. 
dvostranačje proizilazi iz sljedećih uvjeta: (1) iako se nadmeće više političkih stranaka mala magnituda eliminira stranke s manjom biračkom podrškom; (2) obje velike stranke teže ne samo osvajanju većine, nego teže $100 \%$ učinku. Dakle, što je izborna magnituda manja to je niži efekt proporcionalnosti izbornog sistema, a to znači manje šanse malih stranaka da osvoje mandat. Iako te šanse povećava institut kompenzacionih mandata, on još uvijek ne može nadomjestiti negativni efekt male izborne magnitude. Po Nohlenu, kada se veličina izborne jedinice smanjuje, tada se povećava disproporcija između palih glasova i mandata. I obratno, efekat proporcionalnosti izbornog sistema jača ako se povećavaju veličine izbornih jedinica (Nohlen, 1992 : 53). veličina izborne jedinice (izborna magnituda) može, presudno promjeniti efekt izbornog sistema proporcionalne reprezentacije (PR). Čak je i moguće, kao što smo vidjeli, da izborni sistem pređe iz jednog temeljnog tipa (proporcionalni) u drugi (većinski) samo na osnovu promjene veličine izborne magnitude. Tako izbori u izbornim jedinicama ,sa tri mandata su većinski izbori“ (Nohlen, 1992 : 55).

Ako se želi očuvati višestranački sistem s nezavisnim strankama, onda se treba ići na okrupljivanje izbornih jedinica i povećanje izborne magnitude kako bi se formirale izborne jedinice srednje veličine (od 6 do 10 poslanika po izbornoj jedinici) ili, čak, velike izborne jedinice (10 i više poslanika po izbornoj jedinici). U malim izbornim jedinicama izborni sistem proporcionalne reprezentacije gubi svrhu svoga postojanja, svoj raison d'etre.

\section{Izborni sistem, principi političkog predstavništva i kriteriji reprezentativnosti}

Jedna od funkcija kompetitivnih izbora jeste obrazovanje funkcionalnog predstavništva (Nohlen, 1992 : 20) koje počiva na nekoliko principa.

Različiti faktori utiču na konačan dizajn parlamenta, koji predstavlja najviše političko predstavničko tijelo i najviši zakonodavni organ vlasti političke zajednice. Naprimjer, na njegov sastav presudno utiče ustavom utvrđeni broj poslaničkih mjesta i način na koji se u ustavnom sistemu dolazi do toga broja, odnosno kako se on utvrđuje. Svakako da na konačni sastav parlamenta bitno utiču i kriteriji reprezentiranja, odnosno odgovor na pitanje: Koga parlament reprezentira tj. ko su subjekti koje predstavljaju izabrani poslanici u parlamentu? Tek kada se odgovori na ova pitanja na scenu stupaju dizajneri izbornog sistema koji dizajniraju izborni sistem koji treba omogućiti ostvarenje ideje ustavotvorca o reprezentativnosti. Tako izborni sistem, odnosno 
mehanizam izbora predstavnika, biva instrument za konstituiranje parlamenta koji može nekada presudno uticati na konačni sastav parlamenta.

Prvi princip konstituiranja političkog predstavništva je princip većine. $\mathrm{Na}$ tom načelu nastaju većinski izborni sistemi. Pri konstituiranju donjeg doma parlamenta (doma građana) polazi se od pravila većine po kojemu odlučuje većina i shodno tome sastav parlamenta odražava volju većine.

Drugi princip se temelji na načelu proporcionalnog političkog predstavljanja. I na tom načelu nastaju proporcionalni izborni sistemi. U parlamentu su predstavljeni različiti interesi i političke ideologije. Parlament predstavlja „ogledalo nacije“. Osnovno mjerilo za dobijanje mandata je broj osvojenih glasova, a distribucija (alokacija) mandata se vrši među kandidatskim listama proporcionalno broju osvojenih glasova. John St. Mill je posebno preferirao ovaj sistem predstavničke demokracije. "U zaista jednakoj demokraciji svaki će, ili bilo koji dio, biti predstavljen ne neproporcionalno nego proporcionalno. Većina birača uvijek će imati većinu predstavnika, a manjina birača imat će uvijek manjinu predstavnika." (Mill, 1989 : 76). Da bi se to ostvarilo Mill se zalaže za sasvim konkretan projekt Thomasa Harea o proporcionalnoj reprezentaciji, koji je taj autor izložio u svom "Traktatu o biranju predstavnika", objavljenom 1859. godine. ${ }^{9}$ Za ovaj projekat Mill je iznio najveće hvalospjeve tvrdeći da Hareov plan spada "među najveća unapređenja, ikada dostignuta u teoriji i praksi vladavine”. (Mill, 1989 : 81).

Treći princip se temelji na miksanju ova dva sistema i na tom načelu nastaju mješoviti izborni sistemi. Dio parlamentaraca se bira po većinskom, a dio po proporcionalnom izbornom sistemu.

Među prve kriterije reprezentativnosti spada predstavljanje građana, tj birača. Politički predstavnik, parlamentarac, reprezentira sve građane, a ne samo one koji su glasali za njega. Najznačajniji kriterij za reprezentiranje građana je princip jednakosti biračkog prava - načelo ,Jedan čovjek-jedan glasjednaka vrijednost" (Pajvančić, 2008 : 247). Govor koji je održao Edmund Burke $^{10}$ se smatra rodonačelnikom teorije o slobodnom mandatu. Po njemu izabrani predstavnik ima slobodni, neobvezujući mandat jer nije obavezan slijediti upute i želje svojih birača, nego zastupati njihove interese s gledišta cjeline političke zajednice (Arnautović, 2009 : 65).

\footnotetext{
${ }^{9}$ Treatise on the Election of representatives: Parliamentary and Minicipal, London, 1859.

${ }^{10}$ Povodom njegova kandidiranja za drugi mandat u predstavljanju Bristola, $u$ to vrijeme drugog grada u Engleskoj, a neposredno uoči izbora, Burke je održao govor, poznat kao Speech of Bristol Guildhall iz 1780. u kojemu odgovara na kritike biračkog tijela i ocrtava svoje razumijevanje političkog predstavništva.
} 
Drugi kriterij reprezentativnosti je geografska ili teritorijalna reprezentativnost. „Drugi tip reprezentativnosti je teritorijalna ili geografska reprezentativnost koja omogućava da manja i veća naseljena mjesta budu zastupljena u zakonodavnim tijelima“ (Hadžiabdić, 2018 : 221). Skupština Socijalističke Republike Bosne i Hercegovine pred izbore 1990. godine je imala dva doma (bikameralna skupština): Vijeće građana i Vijeće općina. Vijeće općina je brojalo 110 vijećnika i činili su ga predstavnici svake općine po jedan, bez obzira na veličinu teritorije ili broj stanovnika (tada je bilo 109 općina u $\mathrm{BiH}$, plus jedan predstavnik glavnog Grada Sarajevo). ${ }^{11}$ Europska povelja o regionalnoj samoupravi utvrđuje princip učešća regiona u odlučivanja na nivou centralnih vlasti (Pejanović, Sadiković, 2010 : 169-176). Načini reprezentiranja regija u parlamentu mogu biti dizajnirani na različite načine. Naprimjer, da postoji poseban dom regija; da se utvrde izborne jedinice koje se poklapaju sa granicama regija; da se primjeni regionalni princip kod konstituiranja doma građana u federacijama, itd. (Pajvančić, 2008 : 259). Najpoznatiji primjer jednake teritorijalne predstavljenosti je Senat Kongresa SAD. „Senat se danas sastoji od 100 članova, po dva iz svake od 50 država“ (Duraković, 2000 : 122) neovisno o veličini teritorije ili broju stanovnika saveznih država.

Ravnomjerna predstavljenost žena i muškaraca, kao i adekvatna predstavljenost nacionalnih manjina također su važni kriteriji reprezentativnosti. Prilikom formuliranja ovih kriterija može se primjeniti tzv. pozitivna diskriminacija ili afirmativna akcija. Neki od načina pozitivne diskriminacije su: zagarantirana mjesta za žene; oslobađanje od taksi za kandidaturu žena; posebne izborne jedinice za žene; kvota za manje zastupljeni spol na kandidatskim listama; veća financijska pomoć za žene kandidatkinje; zamjena parlamentarca kome je po sili zakona prestao mandat kandidatom istog spola po dubini liste, itd).

Parlament nije samo predstavnišvo građana u najširem smislu te riječi, nego je izraz i političke afilacije birača, pa je samim tim i političko predstavništvo. Izabrani politički predstavnici reprezentiraju i njihove političke subjekte, a ne samo birače koji su ih izabrali. Parlament na taj način tvori dvostruko predstavništvo: predstavništvo građana i predstavništvo političkih subjekata. „Oblik i vrsta izbornog sistema utiče na kvalitet i mogućnost reprezentovanja političkih stranaka.“ (Pajvančić, 2008 : 258). Tako većinski izborni sistemi u pravilu imaju za posljedicu dvostanačku strukturu parlamenta, a

\footnotetext{
${ }^{11}$ Detaljnije o raspodjeli mandata u Vijeću općina SR BiH vidjeti u: Ibrahimagić, Omer, Seizović, Zarije, Arnautović, Suad, 2010, Politički sistem Bosne i Hercegovine Tom I Udžbenik, Promocult, Sarajevo, str. 329-330.
} 
politička posljedica primjene proporcionalnih izbornih sistema je da se u parlamentu političke stranke reprezentiraju proporcionalno podršci koju njihovi kandidati i programi dobiju od strane biračkog tijela.

Demokratsko načelo jednakih izbora nas uči da svaki glas treba da ima jednaku brojčanu vrijednost. Jednakost glasa postiže se u onom slučaju kada na izbornom području jedan mandat otpada na približno jednak broj birača (ili stanovnika), tada se, prema Nohlenu, primjenjuje „ključ jednakog predstavništva“" (Nohlen, 1992 : 58).

\section{Efektivne političke stranke u postdaytonskoj Bosni i Hercegovini}

Prošlo je više od 30 godina od prvih višestranačkih izbora u Bosni i Hercegovini, koji su održani 18. novembra 1990. godine. Bio je to početak procesa tranzicije iz jednopartijskog u višestranački politički sistem. U 1996. godini su održani prvi poslijeratni izbori. Od tada do kraja 2018. godine, kao što se može vidjeti na Grafikonu 1, kao i iz Tabele 1, održano je osam predsjedničkih izbornih ciklusa i osam ciklusa za nacionalno zakonodavstvo i entitetsku vlast (održano je i sedam ciklusa za lokalnu vlast).

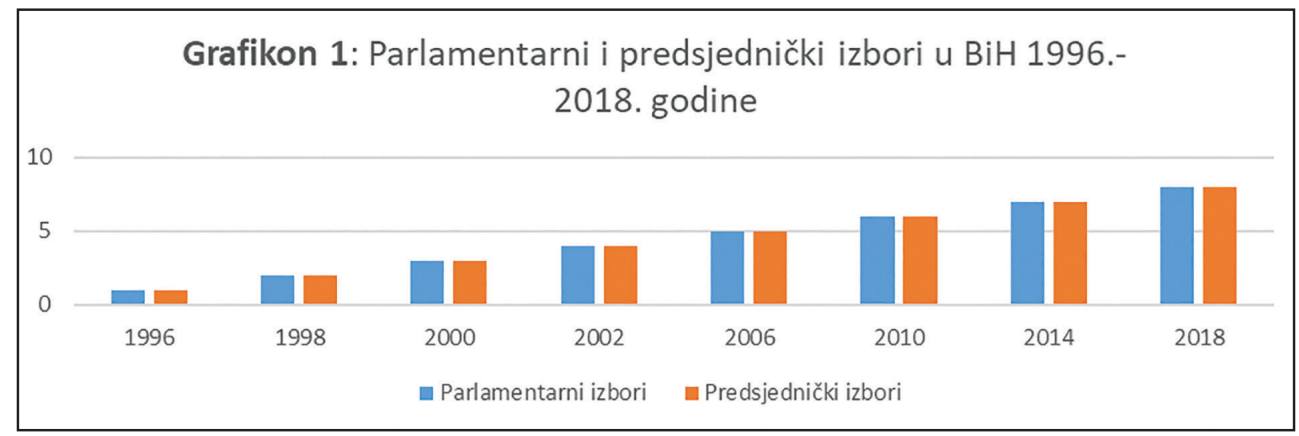

Izvor. S. Arnautović, 2021.

Tokom tog perioda stvorene su, ali i nestale iz političke arene, brojne političke stranke različitih ideoloških smjerova, izborne podrške i organizacijske strukture. ${ }^{12}$ Neke političke stranke koje su 1990. izabrane u nacionalni parla-

\footnotetext{
${ }^{12} \mathrm{O}$ organizacionoj strukturi i generičkim svojstvima političkih stranaka u BiH vidjeti našu istraživačku studiju pod naslovom: „Organizational Structures of Political Parties in CEE Countries: A Case Study on Bosnia and Herzegovina” poglavlje u knjizi „Organizational Structures of Political Parties in Central and Eastern European Countries (Editors: K. Sobolewska-Myślik, B.Kosowska-Gąstol, P.Borowiec), Jagiellonian University Press, Kraków, 2016. (ISBN 978-83-233-4174-1) - str. 59-83; kao i našu istraživačku studiju o prezidencijalizaciji političkih stranaka u BiH: "The Presidentialisation of Political Parties in Bosnia and Herzegovina: A Mitigated Presidentialism" poglavlje u knjizi: "The Presiden-
} 
ment ostale su ,parlamentarne stranke“ i nakon parlamentarnih izbora 2018, a mnoge su u međuvremenu nestale s političke scene. Zašto stranački sistem u Bosni i Hercegovini nije dosegao stabilnost (stabilan stranački sistem), nego ga još uvijek karakterizira atomizirani pluralizam? Zašto se bosanskohercegovački stranački sistem nije jasno profilirao u stabilne ideološke grupe stranačkih porodica na ideološkom kontiniumu lijevo-centar-desno? To su pitanja na koja se trebaju dati odgovori produbljenijim empirijskim istraživanjima primjenom metodološke triangulacije tj. kombiniranim kvantitativnim i kvalitativnim istraživačkim metodama.

Broj političkih subjekata (političkih stranaka i koalicija) koji je ušao u državni parlament je sljedeći: 1996. - šest subjekata; 1998. - deset subjekata; 2000. - 13 subjekata; 2002. - 14 subjekata; 2006. - 12 subjekata; 2010. - 12 subjekata; 2014. - 12 subjekata; 2018. - 14 subjekata. Primjetno je da svaki četvrti izborni ciklus u Parlament uvodi maksimalan broj političkih subjekata - 14 od kojih je npr. 2018. godine u Parlament ušlo ukupno 10 stranaka samostalno i dvije koalicije sa po 7 (HDZBiH i dr.) i 4 (SDS i dr) što je 21 predstavljena politička stranka u državnom parlamentu. Previše stranaka ukazuje na atomizirani pluralizam (Sartori) fragmentirani stranački sistem, a poznato je da je fragmentirani stranački sistem disfunkcionalan, a što se onda direktno prelijeva na disfunkcionalnost cjelokupnog političkog sistema.

Tabela 1 - Broj efektivnih/relevantnih stranaka i rezultati izbora za Predstavnički dom Parlamentarne skupštine BiH 1996.-2018. godina

\begin{tabular}{|c|c|c|c|c|c|}
\hline $\begin{array}{l}\text { Godina } \\
\text { izbora }\end{array}$ & Politički subjekt & $\begin{array}{l}\text { Ukupan } \\
\text { broj važećih } \\
\text { glasova }\end{array}$ & $\begin{array}{l}\text { Ukupan broj } \\
\text { glasova za } \\
\text { politički } \\
\text { subjekt }\end{array}$ & $\begin{array}{l}\text { Procenat } \\
\text { - ukupno } \\
\text { važećih } \\
\text { glasova }\end{array}$ & $\begin{array}{l}\text { Broj } \\
\text { mandata }\end{array}$ \\
\hline \multirow{6}{*}{1996.} & SDA-STRANKA DEMOKRATSKE AKCIJE & \multirow{6}{*}{2399874} & 909970 & 37,91 & 19 \\
\hline & $\begin{array}{l}\text { SRPSKA DEMOKRATSKA STRANKA /SRPSKIH } \\
\text { ZEMALJA/ }\end{array}$ & & 578723 & 24,11 & 9 \\
\hline & HDZ BIH - HRVATSKA DEMOKRATSKA ZAJEDNICA & & 338440 & 14,1 & 8 \\
\hline & $\begin{array}{l}\text { NARODNI SAVEZ ZA SLOBODAN MIR (SAVEZZZA MIR } \\
\text { I PROGRES) }\end{array}$ & & 136077 & 5,67 & 2 \\
\hline & $\begin{array}{l}\text { ZDRUŽENA LISTA BIH (SDP BIH,UBSD, HSS, MBO, } \\
\text { REPUBLIKANCI) }\end{array}$ & & 105918 & apr.41 & 2 \\
\hline & STRANKA ZA BOSNU I HERCEGOVINU & & 93816 & 3,9 & 2 \\
\hline
\end{tabular}

tialisation of Political Parties in the Western Balkans", Editted by G. Passarelli, Palgrave MacMillan, London, 2019. (ISBN 978-3-319-97351-7), https://doi.org/10.1007 /978-3-319-97352-4) - str.73-96; 


\begin{tabular}{|c|c|c|c|c|c|}
\hline $\begin{array}{l}\text { Godina } \\
\text { izbora }\end{array}$ & Politički subjekt & $\begin{array}{l}\text { Ukupan } \\
\text { broj važećih } \\
\text { glasova }\end{array}$ & $\begin{array}{l}\text { Ukupan broj } \\
\text { glasova za } \\
\text { politički } \\
\text { subjekt }\end{array}$ & $\begin{array}{l}\text { Procenat } \\
\text { - ukupno } \\
\text { važećih } \\
\text { glasova }\end{array}$ & $\begin{array}{l}\text { Broj } \\
\text { mandata }\end{array}$ \\
\hline \multirow{10}{*}{1998.} & $\begin{array}{l}\text { KOALICIJA ZA CD BIH (SDA BIH, SNIH, LIBERALI BIH, } \\
\text { GDS) }\end{array}$ & \multirow{10}{*}{1726233} & 583994 & 33,83 & 17 \\
\hline & HDZ BIH - HRVATSKA DEMOKRATSKA ZAJEDNICA & & 200092 & 11,59 & 6 \\
\hline & SLOGA & & 214634 & 12,43 & 4 \\
\hline & SRPSKA DEMOKRATSKA STRANKA & & 162515 & 9,41 & 4 \\
\hline & SDPBIH & & 159871 & 9,26 & 4 \\
\hline & SRS RS & & 118446 & 6,86 & 2 \\
\hline & SOCIJALDEMOKRATI BIH & & 32192 & 1,86 & 2 \\
\hline & NHI-HKDU & & 40080 & 2,32 & 1 \\
\hline & RADIKALNA STRANKA RS & & 27660 & 1,6 & 1 \\
\hline & DNZBIH & & 21452 & 1,24 & 1 \\
\hline \multirow{13}{*}{2000.} & SDP BIH & \multirow{13}{*}{1490221} & 268270 & 18 & 9 \\
\hline & SDA-STRANKA DEMOKRATSKE AKCIJE & & 279548 & 18,75 & 8 \\
\hline & SRPSKA DEMOKRATSKA STRANKA & & 248579 & 16,68 & 6 \\
\hline & HDZ BIH - HRVATSKA DEMOKRATSKA ZAJEDNICA & & 169821 & 11,39 & 5 \\
\hline & STRANKA ZA BIH & & 168995 & 11,34 & 5 \\
\hline & PDP & & 95245 & 6,39 & 2 \\
\hline & KOALICIJA SNSD-DSP & & 66684 & 4,47 & 1 \\
\hline & SOCIJALISTIČKA PARTIJA RS & & 38851 & 2,6 & 1 \\
\hline & SRPSKI NARODNI SAVEZ RS-BILJANA PLAVŠIĆ & & 28125 & 1,88 & 1 \\
\hline & NHI-HKDU & & 23604 & 1,58 & 1 \\
\hline & DNZ BIH & & 19527 & 1,31 & 1 \\
\hline & $\begin{array}{l}\text { BOSANSKOHERCEGOVAČKA PATRIOTSKA STRANKA } \\
\text { (BPS) }\end{array}$ & & 17248 & 1,15 & 1 \\
\hline & DEMOKRATSKA STRANKA PENZIONERA BIH & & 15962 & 1,07 & 1 \\
\hline
\end{tabular}




\begin{tabular}{|c|c|c|c|c|c|}
\hline $\begin{array}{l}\text { Godina } \\
\text { izbora }\end{array}$ & Politički subjekt & $\begin{array}{l}\text { Ukupan } \\
\text { broj važećih } \\
\text { glasova }\end{array}$ & $\begin{array}{l}\text { Ukupan broj } \\
\text { glasova za } \\
\text { politički } \\
\text { subjekt }\end{array}$ & $\begin{array}{l}\text { Procenat } \\
\text { - ukupno } \\
\text { važećih } \\
\text { glasova }\end{array}$ & $\begin{array}{l}\text { Broj } \\
\text { mandata }\end{array}$ \\
\hline \multirow{14}{*}{2002.} & SDA-STRANKA DEMOKRATSKE AKCIJE & \multirow{14}{*}{1228923} & 269427 & 21,92 & 10 \\
\hline & STRANKA ZA BOSNU I HERCEGOVINU & & 136090 & 11,07 & 6 \\
\hline & SRPSKA DEMOKRATSKA STRANKA & & 172544 & 14,04 & 5 \\
\hline & KOALICIJA (HDZ, DEMOKRŠĆANI) & & 114207 & 9,29 & 5 \\
\hline & SDP BIH & & 112258 & 9,13 & 4 \\
\hline & SNSD - SAVEZ NEZAVISNIH SOCIJALDEMOKRATA & & 114591 & 9,32 & 3 \\
\hline & PDP & & 53177 & 4,32 & 2 \\
\hline & SRSRS & & 24559 & 1,99 & 1 \\
\hline & SOCIJALISTIČKA PARTIJA RS & & 22126 & 1,8 & 1 \\
\hline & BOSS - BOSANSKA STRANKA & & 18411 & 1,49 & 1 \\
\hline & STRANKA PENZIONERA UMIROVLJENIKA BIH & & 17588 & 1,43 & 1 \\
\hline & DNZ BIH & & 16454 & 1,33 & 1 \\
\hline & EKONOMSKI BLOK HDU-ZA BOLJITAK & & 16052 & 1,3 & 1 \\
\hline & NHI-HKDU & & 13820 & 1,12 & 1 \\
\hline \multirow{5}{*}{2006.} & SDA-STRANKA DEMOKRATSKE AKCIJE & \multirow{5}{*}{1412078} & 238475 & 16,88 & 9 \\
\hline & STRANKA ZA BOSNU I HERCEGOVINU & & 219487 & 15,54 & 8 \\
\hline & SNSD - SAVEZ NEZAVISNIH SOCIJALDEMOKRATA & & 269468 & 19,08 & 7 \\
\hline & SDP BIH & & 143272 & 10,14 & 5 \\
\hline & SRPSKA DEMOKRATSKA STRANKA & & 108616 & 7,69 & 3 \\
\hline \multirow{7}{*}{2006.} & HDZ BIH - HRVATSKA DEMOKRATSKA ZAJEDNICA & \multirow{7}{*}{1412078} & 69333 & 4,9 & 3 \\
\hline & $\begin{array}{l}\text { HRVATSKO ZAJEDNIŠTVO (HDZ 1990, } \\
\text { HZ-HSS-HKDU.-HDU-DEM.) }\end{array}$ & & 52686 & 3,72 & 2 \\
\hline & $\begin{array}{l}\text { BOSANSKOHERCEGOVAČKA PATRIOTSKA STRANKA } \\
\text { (BPS) }\end{array}$ & & 38474 & 2,72 & 1 \\
\hline & NARODNA STRANKA RADOM ZA BOLIITAK & & 33020 & 2,33 & 1 \\
\hline & PDP & & 28410 & 2,01 & 1 \\
\hline & DNS & & 20100 & 1,42 & 1 \\
\hline & DNZ BIH & & 19807 & 1,4 & 1 \\
\hline
\end{tabular}




\begin{tabular}{|c|c|c|c|c|c|}
\hline $\begin{array}{l}\text { Godina } \\
\text { izbora }\end{array}$ & Politički subjekt & $\begin{array}{l}\text { Ukupan } \\
\text { broj važećih } \\
\text { glasova }\end{array}$ & $\begin{array}{l}\text { Ukupan broj } \\
\text { glasova za } \\
\text { politički } \\
\text { subjekt }\end{array}$ & $\begin{array}{l}\text { Procenat } \\
\text { - ukupno } \\
\text { važećih } \\
\text { glasova }\end{array}$ & $\begin{array}{l}\text { Broj } \\
\text { mandata }\end{array}$ \\
\hline \multirow{12}{*}{2010.} & SDP BIH & \multirow{12}{*}{1641569} & 284435 & 17,32 & 8 \\
\hline & SNSD - SAVEZ NEZAVISNIH SOCIJALDEMOKRATA & & 277819 & 16,92 & 8 \\
\hline & SDA-STRANKA DEMOKRATSKE AKCIJE & & 214300 & 13,05 & 7 \\
\hline & SRPSKA DEMOKRATSKA STRANKA & & 137844 & 8,39 & 4 \\
\hline & SBB & & 130448 & 7,94 & 4 \\
\hline & HDZ BIH - HRVATSKA DEMOKRATSKA ZAJEDNICA & & 114476 & 6,97 & 3 \\
\hline & STRANKA ZA BOSNU I HERCEGOVINU & & 86669 & 5,27 & 2 \\
\hline & HRVATSKA KOALICIJA HDZ 1990-HSP & & 50071 & 3,05 & 2 \\
\hline & NARODNA STRANKA RADOM ZA BOLIITAK & & 49050 & 2,98 & 1 \\
\hline & PDP & & 40007 & 2,43 & 1 \\
\hline & DNS & & 28511 & 1,73 & 1 \\
\hline & DNZ BIH & & 14843 & 0,9 & 1 \\
\hline \multirow{12}{*}{2014.} & SDA-STRANKA DEMOKRATSKE AKCIJE & \multirow{12}{*}{1630920} & 305394 & 18,72 & 10 \\
\hline & SNSD - SAVEZ NEZAVISNIH SOCIJALDEMOKRATA & & 255024 & 15,63 & 6 \\
\hline & SRPSKA DEMOKRATSKA STRANKA & & 211562 & 12,97 & 5 \\
\hline & DEMOKRATSKA FRONTA & & 150767 & 9,24 & 5 \\
\hline & SBB & & 142003 & 8,7 & 4 \\
\hline & $\begin{array}{l}\text { HDZBIH, HSS, HKDUBIH, HSP DR.A.STARČEVIĆ, } \\
\text { HSP HERCEG-BOSNE }\end{array}$ & & 123022 & 7,54 & 4 \\
\hline & SDP BIH & & 108501 & 6,65 & 3 \\
\hline & PDP-NDP & & 50322 & 3,08 & 1 \\
\hline & HDZ 1990 & & 40113 & 2,45 & 1 \\
\hline & $\begin{array}{l}\text { BOSANSKOHERCEGOVAČKA PATRIOTSKA STRANKA } \\
\text { (BPS) }\end{array}$ & & 38318 & 2,34 & 1 \\
\hline & DNS-NS-SRS & & 37052 & 2,27 & 1 \\
\hline & A-SDA & & 22088 & 1,35 & 1 \\
\hline
\end{tabular}




\begin{tabular}{|c|c|c|c|c|c|}
\hline $\begin{array}{l}\text { Godina } \\
\text { izbora }\end{array}$ & Politički subjekt & $\begin{array}{l}\text { Ukupan } \\
\text { broj važećih } \\
\text { glasova }\end{array}$ & $\begin{array}{l}\text { Ukupan broj } \\
\text { glasova za } \\
\text { politički } \\
\text { subjekt }\end{array}$ & $\begin{array}{l}\text { Procenat } \\
\text { - ukupno } \\
\text { važećih } \\
\text { glasova }\end{array}$ & $\begin{array}{l}\text { Broj } \\
\text { mandata }\end{array}$ \\
\hline \multirow{14}{*}{2018.} & SDA-STRANKA DEMOKRATSKE AKCIJE & \multirow{14}{*}{1656516} & 281731 & 17 & 9 \\
\hline & SNSD - SAVEZ NEZAVISNIH SOCIJALDEMOKRATA & & 265593 & 16,03 & 6 \\
\hline & SDP BIH & & 150454 & 9,08 & 5 \\
\hline & $\begin{array}{l}\text { HDZBIH, HSS, HKDUBIH, HSP-HNS. HSP } \\
\text { DR.A.STARČEVIĆ, HDUBIH }\end{array}$ & & 149872 & 9,04 & 5 \\
\hline & SDS-LISTA (SDS-NDP-NS-SRS) & & 162414 & 9,08 & 3 \\
\hline & DF-GS,ŽELJKO KOMŠIĆ: BiH POBJEĐUJE! & & 96174 & 5,8 & 3 \\
\hline & PDP & & 83832 & 5,06 & 2 \\
\hline & SBB & & 68993 & 4,16 & 2 \\
\hline & NAŠA STRANKA & & 48401 & 2,92 & 2 \\
\hline & DNS & & 69289 & 4,18 & 1 \\
\hline & NEZAVISNI BLOK & & 41512 & 2,5 & 1 \\
\hline & POKRET DEMOKRATSKE AKCIJE & & 38417 & 2,31 & 1 \\
\hline & SOCIJALISTIČKA PARTIJA RS & & 31321 & 1,89 & 1 \\
\hline & A-SDA & & 30482 & 1,84 & 1 \\
\hline
\end{tabular}

Izvor: S. Arnautović, 2021.

Iz kvantifikacije iznesene u Tabeli 1 može se zaključiti da su sve elektivne stranke izabrane u državni parlament $\mathrm{BiH}$ na Općim izborima 2018. godine još uvijek aktivne i da čine jezgro bosanskohercegovačke političke arene. Međutim, za očekivati je da će ta arena na Generalnim izborima 2022. godine biti “obogaćena” još jednim brojem jakih stranaka koje su svoju lokalnu relevantnost pokazale na Lokalnim izborima 2020. godine.

\section{Izborni sistem i pravila izbornog postupka - Opći izbori 1996-2002. godine}

Na Slici 1 možemo vidjeti komparativni prikaz osnovnih elemenata izbornog sistema, i to: način glasanja (tip glasačkog listića); izborne jedinice; metoda za prenos glasova u mandate (matematička formula) i prikaz tih elemenata karakterističan za aktuelni izborni sistem u Bosni i Hercegovini.

Međutim, prvi postdaytonski izbori održani 1996. godine su imali drugačije elemente izbornog sistema. Članovi Predstavničkog doma Parlamentarne skupštine BiH su se birali u dvije višečlane izborne jedinice (Federacija BiH 
i Republika Srpska) po sistemu at-large (cijela teritorija entiteta jedna izborna jedinica). Formula za preračun mandata je bila kombinacija izborne kvote (Hare) i D'Hondtove formule (izbornog količnika). "I zastupnici u parlamentima bh. entiteta birani su na sličan način....” (Herceg, Tomić, 1998 : 142), "na bazi zatvorenih stranačkih listi" (Hadžiabdić, 2018 : 46). ${ }^{13}$

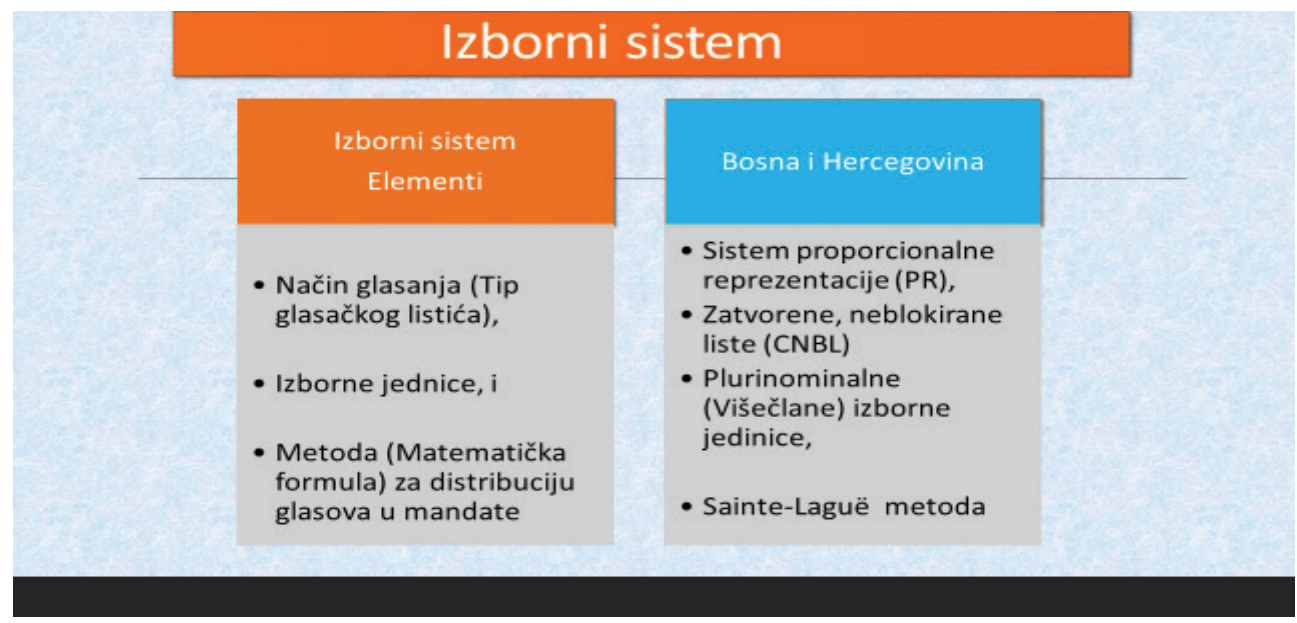

Slika 1: Komparativni prikaz osnovnih elemenata izbornog sistema Izvor. S. Arnautović, 2021.

Prije općih izbora 1998. godine održani su lokalni izbori 1997. i vanredni izbori u Republici Srpskoj. Drugi Opći izbori u BiH su održani u septembru 1998. godine. To je period kada se uvode značajne "tehničke" izmjene u izborno zakonodavstvo u BiH. ${ }^{14}$ Najznačajnija promjena je u pogledu formule za preračun glasova u mandate i umjesto D'Hondtove formule uvodi se formula Saint Laguë. Također, uvedena je odredba o karakteru slobodnog mandata. "Prvi put je propisano da mandat pripada izabranom kandidatu, a ne strankama ili koalicijama, i ne može se mijenjati ili oduzeti osim konačnom odlukom PIK-a” (Hadžiabdić, 2018 : 62). Nadalje, uvedene su novine kod procesa registracije političkih stranaka, podnošenja imovinskih kartona, posmatranja izbora i, što treba posebno naglasiti, u vezi sa boljom zastupljenosti žena na kandidatskim listama.

Za opće izbore koji su održani u novembru 2000. godine Pravila i propisi Privremene izborne komisije (PIK) su prilagođeni odredbama iz Nacrta

\footnotetext{
${ }^{13}$ Praktičan primjer alokacije mandata sukladno ovom izbornom modelu vidjeti u. Hadžiabdić, 2018, str. 46-47.

${ }^{14}$ Pravila i propisi Privremene izborne komisije, „Službeni list BiH“, br. 15/98 i 20/98.
} 
stalnog Izbornog zakona $\mathrm{BiH}$, koji je Parlamentarna skupština BiH usvojila tek augusta 2001. godine. ${ }^{15} \mathrm{U}$ ranijim izborima (1996-1998) Privremena izborna komisija je vodila proces registracije političkih stranaka za učešće na izborima. Međutim, na ovim izborima od stranaka se tražilo da budu registrirane kod nadležnog sudskog organa, ${ }^{16}$ a Privremena izborna komisija je zadržala nadležnost u pogledu ovjere političke stranke za učešće na izborima. Prilikom ovjere političke stranke PIK je tražila sljedeće dokumente: potreban broj potpisa podrške; ${ }^{17}$ potpisanu izjavu da će politička stranka poštovati Opći okvirni sporazum za mir u Bosni i Hercegovini, Izborni kodeks ponašanja, kao i Pravila i propise Privremene izborne komisije; naziv političke stranke koji će se pojaviti na glasačkom listiću; listu izbornih jedinica u kojima politička stranka namjerava podnijeti liste kandidata, kao i listu za kompenzacijske mandate; depozit za ovjeru; ${ }^{18}$ političku platformu; potvrdu o registraciji; i finansijski izvještaj. ${ }^{19}$ Novina za ove izbore bila je i uvođenje lista nezavisnih kandidata, koje su mogli formirati nezavisni kandidati ovjereni za istu izbornu jedinicu.

Tokom priprema za općinske izbore koji su održani u aprilu 2000. godine Privremena izborna komisija usvojila je nekoliko značajnih izmjena koje se

\footnotetext{
${ }^{15}$ Pravila i propisi OSCE su se mijenjali i dograđivali neposredno pred izbore i sukcesivno tokom cijele 2000. izborne godine što je suprotno međunarodnim standardima o fer i poštenim izborima. Vidjeti "Službeni glasnik BiH" broj: 1/00, 2/00, 7/00, 9/00, 11/00, 16/00, 18/00, 20/00, 21/00, 25/00 i 26/00. Izborni zakon BiH je objavljen u "Službenom glasniku BiH", broj: 23/01 od 19.09.2001. godine.

${ }^{16}$ Ovdje treba istaći da taj sudski organ nije najviši sud u državi nego kantonalni, odnosno općinski sudovi. Ta činjenica, kao i činjenica da nikada nije donešen novi, postdaytonski, krovni zakon o političkim strankama na nivou $\mathrm{BiH}$, uvjetovala je da sudovi različito prilaze pitanjima registracije pojedinih političkih stranaka.

${ }^{17} \mathrm{Za}$ ove izbore smanjen je broj potpisa podrške koji je politička stranka morala prikupiti, ali je uvedeno pravilo da jedan birač može dati potpis podrške samo jednoj političkoj stranci ili nezavisnom kandidatu, što je proces provjere učinilo znatno težim. Političke stranke su morale podnijeti listu od najmanje 3.000 potpisa podrške ukoliko su se željele kandidirati za izbore na nivou Bosne i Hercegovine, 2.000 potpisa podrške ukoliko su se željele kandidirati za izbore na entitetskom nivou i 500 potpisa podrške ukoliko su se željele kandidirati samo na kantonalnom nivou. Političke stranke su bile izuzete od obaveze prikupljanja potpisa podrške ukoliko član te političke stranke ima mandat na istom izbornom nivou za koji se politička stranka prijavljuje. Da bi se primijenila ova odredba, politička stranka je morala podnijeti potpisanu izjavu nosioca mandata da je nosilac mandata bio član te političke stranke u vrijeme kada je dobio mandat i da je još uvijek član te političke stranke.

${ }^{18}$ Iznos depozita za ovjeru je također značajno promijenjen i ovisio je o najvišem nivou vlasti za koji se politička stranka prijavljuje za ovjeru. Tako je za izbore za predsjednika i potpredsjednika Republike Srpske ili za Predstavnički dom Parlamentarne skupštine Bosne i Hercegovine depozit za ovjeru iznosio $10.000 \mathrm{KM}$, za izbore na nivou entiteta, osim za predsjednika i potpredsjednika Republike Srpske, depozit za ovjeru je iznosio $5.000 \mathrm{KM}$ i za izbore na nivou kantona depozit za ovjeru je iznosio 2.000 KM. Kada su u pitanju nezavisni kandidati, broj potpisa podrške, kao i visina depozita za ovjeru, bili su upola niži od onog koji je dat za političke stranke.

${ }^{19}$ OSCE - Misija u BiH, Privremena izborna komisija, Pravila i propisi, "Službeni glasnik BiH”, broj: 18/2000 od 11. jula 2000.
} 
odnose na sam izborni sistem. Prije svega, zadržan je sistem proporcionalne zastupljenosti, prema metodi Sainte-Laguë, ${ }^{20}$ ali su uvedene slabo strukturirane stranačke liste (ordinalna glasačka metoda). ${ }^{21} \mathrm{Na}$ taj način biračima je data mogućnost ne samo da biraju za koju političku stranku žele glasati, nego i da unutar liste kandidata odabrane političke stranke biraju one i onoliko kandidata koliko oni to žele. Kao što smo istakli, mandati su se i dalje raspodjeljivali prema metodi Sainte-Laguë, ali oni kandidati koji su dobili najmanje 3\% glasova koje je osvojila njegova politička stranka ili koalicija prvi su dobijali mandate. ${ }^{22} \mathrm{Na}$ ovaj način Privremena izborna komisija željela je, kao što je pojašnjavano biračima i javnosti, pojačati odgovornost izabranih zvaničnika prema njihovom biračkom tijelu.

Isto tako, kao značajna novina, za „treće opće izbore u BiH“ (Herceg, Tomić, 2001 : 77) tj. za izbore za Predstavnički dom Parlamentarne skupštine Bosne i Hercegovine, Predstavnički dom Parlamenta Federacije Bosne i Hercegovine i za Narodnu skupštinu Republike Srpske, uvedene su, kao što se vidi na Shemi 1, višečlane izborne jedinice (članovi 1102, 1103, 1202, i 1302 Pravila i propisa PIK-a) ${ }^{23}$ kao i kompenzacijski mandati (član 1106 Pravila i propisa PIK-a), a za izbore za predsjednika i potpredsjednika Republike Srpske uveden je sistem preferencijalnog glasanja, koji će kao preuranjen eksperiment za bosanskohercegovačko podneblje vrlo brzo biti napušten već na narednim izborima.

\footnotetext{
${ }^{20}$ Prema članu 1105 Pravila i propisa u kojem se govori o raspodjela mandata u izbornim jedinicama, utvrđeno je sljedeće: "U svakoj izbornoj jedinici mandati se raspodjeljuju na sljedeći način: 1) za svaku političku stranku, listu nezavisnih kandidata i koaliciju, ukupan broj važećih glasova koje je politička stranka ili koalicija osvojila dijeli se sa $1,3,5,7,9,11$, itd. sve dok je to potrebno za tu raspodjelu mandata. Brojevi koji se dobiju ovom serijom dijeljenja su "količnici“". 2) Broj glasova za nezavisnog kandidata je količnik tog kandidata. Količnici se redaju od najvećeg do najmanjeg. Mandati se dijele po redu, počev od najvećeg količnika, dok se ne raspodijele svi mandati izborne jedinice za određeni organ."

${ }^{21}$ PIK je ove liste u javnosti prezentirao kao „otvorene liste“. Međutim, teorijski gledano otvorene liste su nešto sasvim drugo od ovoga što je uvedeno u izborni sistem u BiH. Ovdje se radi o zatvorenim, neblokiranim listama (CNBL - Closed, Non-Blocked Lists).

${ }^{22}$ Ovaj ,unutarnji“ izborni prag za kandidate na stranačkoj listi će se povećati na 5\% za izbore 2002. godine, kako je to utvrđeno članom 9.9 stav 2 stalnog Izbornog zakona $\mathrm{BiH}$ ("Službeni glasnik BiH“, broj: 23/01, 7/02, 9/02, 20/02, 25/02, 4/04 i 20/04.)

${ }^{23} \mathrm{Za}$ izbor Predstavničkog doma PSBiH iz $\mathrm{FBiH}$ uvedeno je 5 višečlanih izbornih jedinica koje su uglavnom obuhvatale područja po dva spojena kantona u FBiH (izborna jedinica 5 je obuhvatala i dio Brčko distrikta $\mathrm{BiH}$ ), a u RS su uvedene 3 višečlane izborne jedinice koje su se poklapale sa geografskim područjima RS (koje je takvo i danas). Za izbor Predstavničkog doma Parlamenta Federacije BiH uvedeno je 12 višečlanih izbornih jedinica, a za izbor Narodne skupštine RS uvedeno je 6 višečlanih izbornih jedinica (danas ih ima 9).
} 


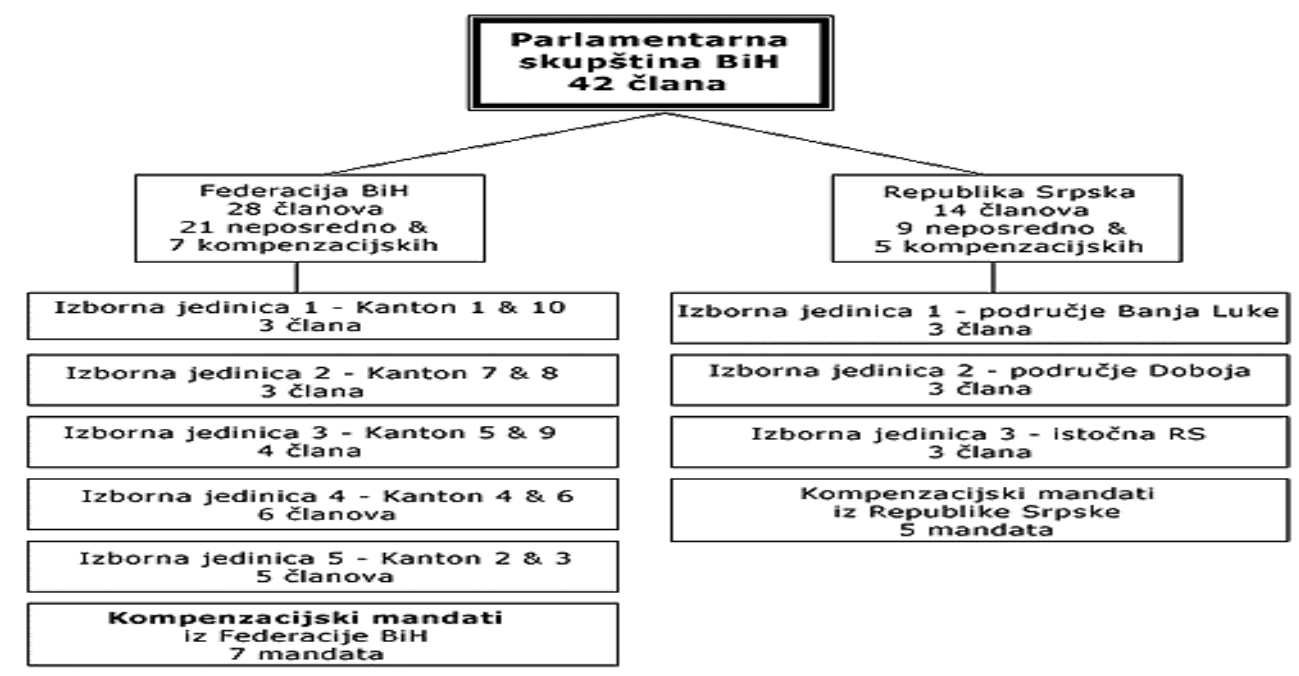

Shema 1: Višečlane izborne jedinice za izbor članova Predstavničkog doma Parlamentarne skupštine Bosne i Hercegovine

\section{Izborne jedinice i izborna magnituda}

Na ovom mjestu posvetićemo se kraćoj analizi izbornih jedinica 1, 2 i 3 iz Republike Srpske za Predstavnički dom Parlamentarne skupštine BiH kako bismo dokazali da je u tom izboru narušeno načelo jednakosti, te naglasili potrebu za reformom i redizajniranjem ovih izbornih jedinica jednako kao i onih pet višečlanih izbornih jedinica iz Federacije BiH za donji dom državnog parlamenta.

Iz tabele koja slijedi (Tabela 2) vidi se u ovom slučaju očito odstupanje od načela jednakosti glasa što predstavlja klasični mallaportioment. Naime, iz priložene tabele je uočljivo da Izborna jedinica 1 (Banjalučka regija) ima 570.865 registriranih birača i da direktno šalje u Predstavnički dom PSBiH 3 poslanika. Izborna jedinica 2 (Dobojska regija) ima 393.328 registrirana birača i šalje u Predstavnički dom PSBiH, također 3 poslanika. Izborna jedinica 3 (Trebinjska regija) ima 296.404 birača i šalje u Predstavnički dom PSBiH, također, 3 poslanika. U ovom slučaju IJ 1 ima $>274.461$ birača više od broja birača registriranih u IJ 3, a daje isti broj poslanika u PDPSBiH. Dakle, za jedan mandat u IJ 1 potrebno je 190.288 glasova, a u IJ3 131.109 glasova. 
Suad Arnautović: Geneza izbornih procesa u Bosni i Hercegovini od 1996. do 2018. godine i moguće promjene...

Tabela 2 Izborne jedinice za Predstavnički dom Parlamentarne skupštine BiH iz Republike Srpske

\begin{tabular}{lllll}
\hline Izborna jedinica & Magnituda & Broj općina & Broj birača* & "Težina" jednog mandata \\
\hline Izborna jedinica 124 & 3 & 21 & 570.865 & $190.288,33$ \\
\hline Izborna jedinica 225 & 3 & $15^{* *}$ & 393.328 & $131.109,33^{*}$ bez Brčkog \\
\hline Izborna jedinica 32 $^{26}$ & 3 & 28 & 296.404 & 318.857 \\
\hline
\end{tabular}

*Odluka o zaključivanju i potvrđivanju izvoda iz Centralnog biračkog spiska za Opće izbore 2018. godine i objavljivanje broja birača za svaku izbornu jedinicu ("Službenik glasnik BiH", broj: 62/18)

**Uključujući građane Brčko distrikta BiH

U raspravi o tome kako politička geometrija, politička geografija, tj. dizajniranje izbornih jedinica i određivanje izborne magnitude utječe na političke posljedice izbornog sistema, pa samim tim i na oblikovanje stranačkog sistema u BiH pomoći će nam bogato empirijsko komparativno iskustvo od 1996. godine do danas koje nam može poslužiti za izvođenje određenih zaključaka i zaokruživanje generalizacija o političkoj prirodi izbornog sistema (modela) u Bosni i Hercegovini.

Podsjetimo na prvi ,sociološki zakon” Mauricea Duvergera koji je ustvrdio da "proporcionalni izborni sistem potiče višestranački sistem s krutim frontama i nezavisnim strankama. Čini to tako što postojećim strankama omogućuje da samostalno sudjeluju u izborima te potiče frakcioniranje starih i nastanak novih stranaka". (Kasapović, 2003 : 69). Međutim, šta se dešava kada se u okviru sistema proporcionalne reprezentacije tvore male izborne jedinice (u smislu izborne magnitude)? Da li se višestranačje zadržava u izbornoj jedinici u kojoj je izborna magnitude 3 ?! Prema članu 9.3 Izbornog zakona BiH utvrđene su tri izborne jedinice iz Republike Srpske od koje svaka daje po 3 poslanika u Predstavnički dom Parlamentarne skupštine Bosne i Hercegovine, odnosno ukupno 9 direktno biranih poslanika.

\footnotetext{
${ }^{24} 1$ Izborna jedinica 1 sastoji se od gradova: Banja Luka i Prijedor i općina: Krupa na Uni, Novi Grad, Kozarska Dubica, Gradiška, Laktaši, Srbac, Prnjavor, Petrovac, Oštra Luka, Čelinac, Istočni Drvar, Ribnik, Mrkonjić Grad, Jezero, Kneževo, Kotor Varoš, Šipovo, Kupres i Kostajnica i bira tri člana, ${ }^{25} 2$ Izborna jedinica 2 sastoji se od gradova: Doboj i Bijeljina, općina Derventa, Brod, Vukosavlje, Šamac, Donji Žabar, Modriča, Pelagićevo,Petrovo, Lopare, Ugljevik, Teslić i Stanari i Brčko distrikta $\mathrm{BiH}$ i bira tri člana,

${ }^{26} 3$ Izborna jedinica 3 sastoji se od gradova Trebinje i Zvornik i općina: Osmaci, Šekovići, Vlasenica, Bratunac, Srebrenica, Sokolac, Han Pijesak, Istočna Ilidža, Istočni Stari Grad, Istočno Novo Sarajevo, Trnovo, Pale, Rogatica, Višegrad, Istočni Mostar, Nevesinje, Kalinovik, Gacko, Foča, Novo Goražde, Čajniče, Rudo, Berkovići, Ljubinje, Bileća i Milići i bira tri člana.
} 
Na primjeru našeg izbornog sistema vidimo da mala izborna magnitude „guši” politički pluralizam u tim izbornim jedinicama i iz sistema proporcionalne reprezentacije (PR) defacto prelazi u većinski izborni sistem.

U vezi sa izbornom magnitudom Nohlen razlikuje male izborne okruge, izborne okruge srednje veličine i velike izborne okruge (Nohlen, 1992 : 52).

Različiti izborni okruzi, po ovom autoru, mogu biti ovih veličina:

\begin{tabular}{|l|l|}
\hline Broj mandata u izbornom okrugu & Podtipovi izbornih okruga sa više mandata \\
\hline $2-5$ & mali izborni okruzi \\
\hline $6-10$ & izborni okruzi srednje veličine \\
\hline 10 i više & veliki izborni okruzi \\
\hline
\end{tabular}

Izvor, Nohlen, 1992: 52

U Tabeli 3 smo istakli da od sedam izbornih ciklusa u izbornim jedinicama 1, 2 i 3 iz RS za Predstavnički dom PSBiH samo na izborima 2000. u IJ1, te na izborima 2018. u IJ1 i IJ3 su mandate osvojile tri političke stranke, a u svim ostalim izbornim ciklusima i u sve tri izborne jedinice mandate su osvajale samo po dvije stranke. Dakle, prevalirajući učinak male magnitude i u sistemu proporcionalne reprezentacije (PR) je dvostranačje.

Tabela 3: Broj stranaka koje osvajaju mandate iz tri izborne jedinice iz Republike Srpske u Predstavničkom domu PSBiH od 2000. do 2018.

\begin{tabular}{lccc}
\hline Godina izbora & Izborna jedinica 1/Br. Stranaka & Izborna jedinica 2/Br stranaka & Izborna jedinica 3/Br. stranaka \\
\hline 2000. & 3 & 2 & 2 \\
\hline 2002. & 2 & 2 & 2 \\
\hline 2006. & 2 & 2 & 2 \\
\hline 2010. & 2 & 2 & 2 \\
\hline 2014. & 2 & 2 & 2 \\
\hline 2018. & 3 & 2 & 3 \\
\hline
\end{tabular}

Izbor: S. Arnautović, 2021. 
Suad Arnautović: Geneza izbornih procesa u Bosni i Hercegovini od 1996. do 2018. godine i moguće promjene...

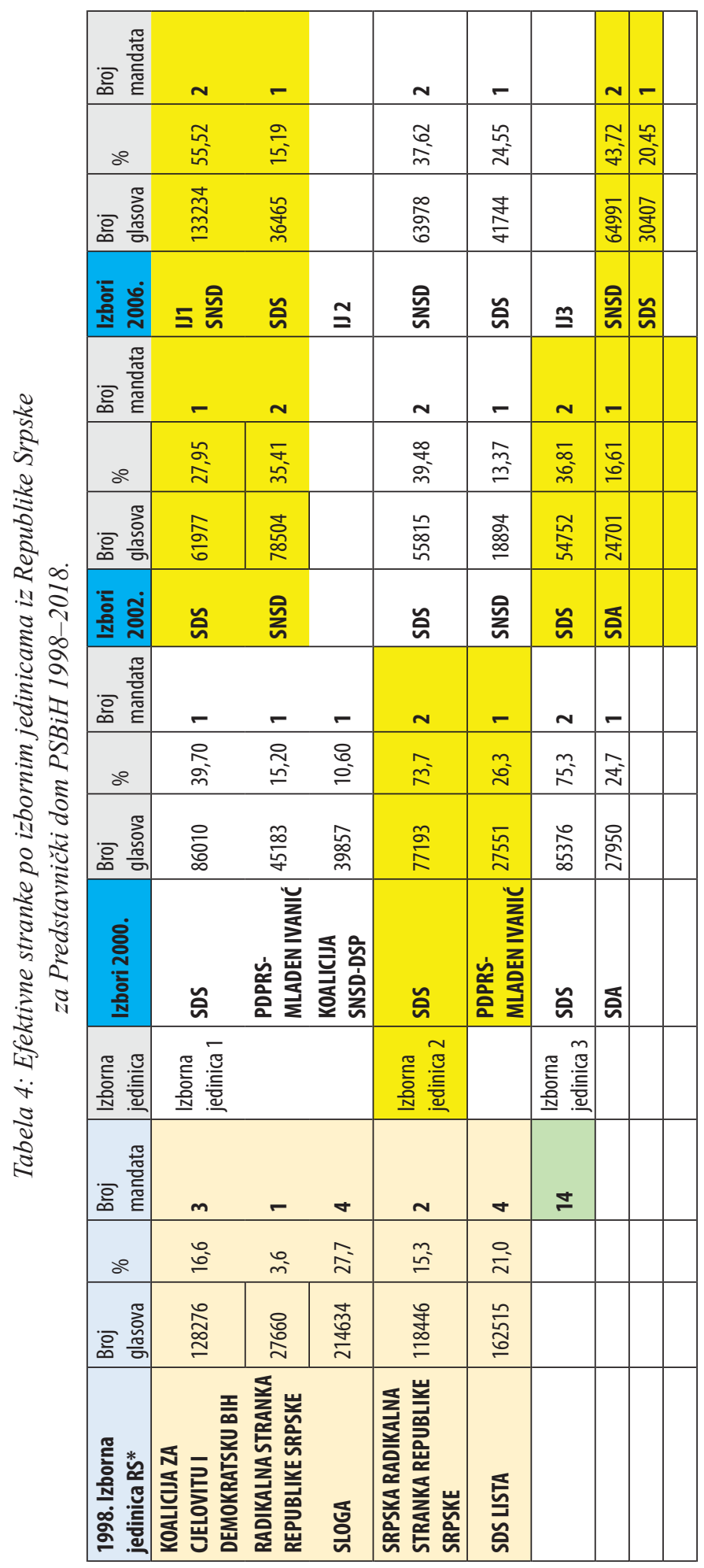




\begin{tabular}{|c|c|c|c|c|c|c|c|c|}
\hline 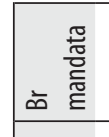 & - & - & - & $\sim$ & - & & - & - \\
\hline & 离 & $\underset{\Phi}{\stackrel{\Phi}{a}}$ & $\stackrel{\approx}{\check{\Sigma}}$ & 怘 & $\frac{0}{2}$ & & 善 & $\overline{\bar{i}}$ \\
\hline & 甍 & 芯 & 縍 & 商 & 胥 & & 莺 & 高 \\
\hline & 玉䒺 & 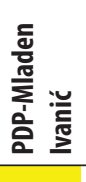 & 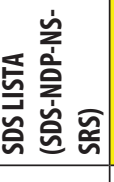 & 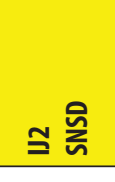 & 施 & $\cong$ & 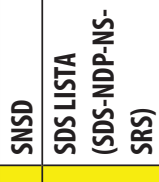 & \\
\hline & n & - & & $\sim$ & - & & - & \\
\hline & $\stackrel{m}{\varpi}$ & Б্ర్త & & 恧 & 岕 & & 章高 & \\
\hline & 兽 & 吕 & & 皆 & 号 & & 总 & \\
\hline & 产 & 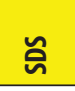 & & 虽 & 商 & & 合 & \\
\hline & $\sim$ & - & & $\sim$ & - & & - & \\
\hline$\therefore$ & $\underset{\sigma}{\tilde{\sigma}}$ & $\stackrel{0}{\underline{s}}$ & & 总 & $\underset{\infty}{\approx}$ & & $\frac{0}{0}$ & \\
\hline & 旁 & 若 & & 蔉 & 獣 & & 苂 & \\
\hline 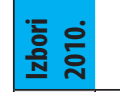 & 总 & 㟔 & & 产 & 㟔 & & $\tilde{a}$ & \\
\hline 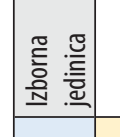 & 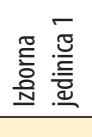 & & & 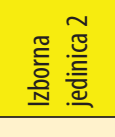 & & 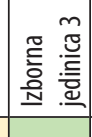 & & \\
\hline 离离 & $\mathrm{m}$ & - & $\sigma$ & $\sim$ & $\sigma$ & \pm & & \\
\hline$\therefore$ & $\stackrel{\circ}{\circ}$ & $\stackrel{\circ}{m}$ & $\lesssim$ & $\stackrel{m}{n}$ & 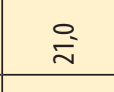 & & & \\
\hline 畐彦 & 怘 & 高 & 薄 & 橲 & 产 & & & \\
\hline 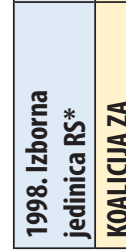 & & & & 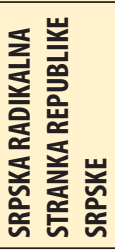 & 畄 & & & \\
\hline
\end{tabular}


Tabela 4 nam dokazuje tezu da što je izborna magnitude manja, to je niži učinak proporcionalnosti izbornog sistema, odnosno da su tada manje šanse malih stranaka. "U izbornom okrugu sa tri mandata relativni broj glasova (u postotku) koji stranka mora doseći da bi sudjelovala u dobivanju mandata jest oko 18\%" (Nohlen, 1992 : 52). Izborni ciklusi od 2000. do 2018. godine, također, pokazuju uočljivu razliku u "težini" mandata, tako da pretpostavljeni apportionment (raspodjela mandata) prelazi u mallaportionment (nejednaka težina glasova po jednom mandatu). Naprimjer, u izborima 2018. godine SNSD-u je bilo potrebno 145.940 glasova ili 41,11 \% važećih glasova za osvajanje jednog mandata u IJ3, dok je SDS LISTI (SDS-NDP-NS-SRS) bilo potrebno 95.626 ili 26,94 glasa, a DNS-u 24.867 ili 14,01 glas.

Broj efektivnih (elektivnih) stranaka (stranaka koje su dobile mandate u Predstavničkom domu PSBiH) u ovim izbornim jedinicama od 2000. do 2018., što se može vidjeti iz Tabele 3, dokazuje tezu da mala izborna magnituda de jure izborni sistem proporcionalne reprezentacije (PR) de jure, pretvara u većinski izborni system, de facto.

\section{Opći izbori 2002-2018. godine}

Naredni izborni ciklusi održani su po odredbama stalnog Izbornog zakona $\mathrm{BiH}$ čije je donošenje bila obaveza iz člana V Aneksa 3 Daytonskog mirovnog sporazuma. Njegovom usvajanju su prethodili "teški" pregovori ključnih političkih aktera u $\mathrm{BiH}$, ali oni nisu urodili plodom. Zato je najprije Visoki predstavnik nametnuo Izborni zakon $\mathrm{BiH}$, a onda je Parlamentarna skupština BiH isti usvojila u august 2001. godine. Ovaj zakon je objavljen u „Službenom glasniku BiH” broj: 23/01. Nakon toga su u više navrata uslijedile „tehničke” izmjene Izbornog zakona BiH. ${ }^{27}$

Opći izbori 2002, 2006, 2010, 2014. i 2018. godine ipak nisu polučili bitnije promjene u pogledu karaktera političkog predstavništva, a niti u samom izbornom sistemu, osim one koja se desila pred izbore 2002. godine. Naime, najbitnija promjena u pogledu političkog predstavništva odnosila se na implementaciju Odluke Ustavnog suda $\mathrm{BiH}$ o konstitutivnosti naroda (predmet $\mathrm{U}$ 5/98), na cijeloj teritoriji $\mathrm{BiH} .{ }^{28}$ Kako su izvršene promjene u entitetskim ustavima bilo je potrebno i izborno zakonodavstvo prilagoditi novim ustavnim

\footnotetext{
${ }^{27}$ Izvršeno je ukupno 20 izmjena Izbornog zakona BiH?! Posljednja izmjena je objavljena u "Službenom glasniku BiH" broj: 41/20 i odnosila se na izbore u Gradu Mostaru.

${ }^{28}$ Radi se, ustvari, o četiri djelomične odluke Ustavnog suda BiH, objavljene u "Službenom glasniku BiH", broj: 11/00, 17/00, 23/00, kao i Četvrta Djelimična odluka U 5/98 IV donešena 18. i 19. augusta 2000. godine. O tome vidjeti Bilten Ustavnog suda BiH br. 4/2001.
} 
rješenjima, naročito u pogledu izbora po dva potpredsjednika entiteta, potom u vezi sa sastavom i izborom Doma naroda Parlamenta Federacije BiH, kao i izborom Vijeća naroda Republike Srpske. ${ }^{29}$ Također, uvedena je ustavna obaveza o minimalnoj zastupljenost od 4 predstavnika konstitutivnih naroda $\mathrm{u}$ entitetskim parlamentima. Ostalih suštinskih izmjena u pogledu karaktera političkog predstavništva i vezano s tim izbornog zakonodavstva nakon izbora 2002. godine nije bilo. ${ }^{30}$ Ustvari, može se reći da su najznačajnije promjene uvedene na lokalnom nivou, kao što je direktni izbor načelnika općina i gradonačelnika gradova (osim u Mostaru, Sarajevu i Brčko distriktu BiH), te zagarantirani izbor pripadnika nacionalnih manjina u općinama sa više od 3\% takvih pripadnika.

Jedan od razloga tome su ,propali” dogovori u vezi sa ustavnom reformom 2006. godine ("Aprilski paket”), kao i dogovori o ustavnoj reformi u jesen 2009. godine ("Butmirski proces"). Ponuđeni paket ustavnih rješenja pod nazivom „Aprilski paket” bio je najbliži za usvajanje, ali nije uspio zadobiti dovoljan broj glasova u Predstavničkom domu PSBiH. Nadalje, paket ustavnih promjena dogovaran u vojnoj bazi u Butmiru kod Sarajeva nije uspio, čak, ni doći na dnevni red sjednice Predstavničkog doma PSBiH. Ti pregovori, koje je "traljavo" pripremio i vodio Karl Bildt doživjeli su totalni fijasko.

\section{Prijedlozi za novi bosanskohercegovački društveni ugovor}

Pogrešna formula da se izgradnja demokracije u BiH može obaviti uz česte i uzastopne izborne cikluse (elektorska demokracija) uz prilagođavanje izbornog sistema željama međunarodne zajednice ili, čak, pojedinih subjekata te zajednice je politički, materijalno, organizaciono i kadrovski iscrpila i domaće i strane faktore. U principu nisu postignuta očekivani efekti, jer se na kraju toga procesa sve vratilo na početak trijumfom nacionalnih stranaka na općim izborima 2002., 2006., 2014. i 2018. godine.

Zato bi se prvo trebalo ići na promjenu Ustava $\mathrm{BiH}$, a potom Izbornog zakona $\mathrm{BiH}$ i tek onda ići na organizaciju narednih izbora.

U tom kontekstu, a u cilju pojednostavljenja procedure donošenja odluka suvislo je razmotriti mogućnost obrazovanja jednodomnog bosanskohercegovačkog parlamenta, koji bi kao "ogledalo društva" odslikavao strukturu

\footnotetext{
${ }^{29}$ Podsjetimo da Dom naroda Parlamenta Federacije BiH i Vijeće naroda RS imaju asimetrične nadležnosti.

${ }^{30} \mathrm{O}$ detaljima svih izmjena izbornog zakonodavstva pažljiviji čitalac može vidjeti u: Hadžiabdić, 2018 str. 71-85.
} 
bih. društva, odnosno cijeli spektar političkih snaga i dominantnih društvenih grupa, kao i civilnog društva.

U pitanjima koja bi se tačno specificirala u Ustavu BiH, a koja spadaju $\mathrm{u}$ vitalni nacionalni interes pojedinih etničkih grupa, iz sastava Parlamenta $\mathrm{BiH}$ mogli bi se izdvojiti pripadnici svake etničke grupe formirajući ad hoc domove naroda za usaglašavanje i zaštitu vitalnog nacionalnog interesa određene etničke grupacije. Etnička grupa koja je pokrenula pitanje vitalnog nacionalnog interesa $\mathrm{u}$ Parlamentu $\mathrm{BiH}$ imala bi pravo veta $\mathrm{u}$ pogledu donošenja odluka Parlamenta BiH sve do odluke Ustavnog suda BiH.

U smislu pojednostavljenja političkog predstavljanja u i izvan Bosne i Hercegovine neophodno bi bilo birati jednog predsjednika države koji bi Ustavom podijeljenu nadležnost dijelio sa premijerom vlade. Predsjednik države, koji bi imao jednog zamjenika i dva potpredsjednika, bi se birao po dvokružnom većinskom izbornom sistemu glasanjem birača sa cijele teritorije države po principu "jedan čovjek - jedan glas - jednaka vrijednost" s mandatom od pet godina.

Parlament BiH bi se trebao birati po personaliziranom sistemu proporcionalne reprezentacije (slično izbornom modelu SR Njemačke) sa sistemom slabo struktuiranih lista. Neophodno je uvesti izborni prag (prohibitivnu klauzulu) od 5\% u cijeloj zemlji odnosno na nivou države.

Izbor Parlamenta $\mathrm{BiH}$, kojeg bi činilo 120 predstavnika, mogao bi se izvršiti personaliziranim proporcionalnim izbornim postupkom sa dva glasa birača:

- jedan glas u uninominalnoj izbornoj jedinici (regiji), čime bi se izabralo 60 ili 50\% predstavnika u jednočlanim izbornim jedinicama po izbornom sistemu relativne većine ("prvi dobija mjesto") ili korištenjem preferencijalnog sistema;

- jedan glas na nivou države kao jednoj izbornoj jedinici (at large), čime bi se izabralo preostalih 60 ili 50\% članova Parlamenta, a izbor bi se vršio prema listovnom sistemu proporcionalne reprezentacije koristeći se sistemom slabo struktuiranih lista.

Dugoročni i stabilni razvoj demokracije u Bosni i Hercegovini zahtjeva ostvarenje konstitutivnosti građanina $\mathrm{BiH}$ na cijeloj teritoriji $\mathrm{BiH}$, što podrazumijeva promjene u ustavno-pravnom sistemu kako države, tako i nižih nivoa vlasti. Taj napor treba da rezultira punom ravnopravnošću etničkih grupa i ostvarenju svih drugih sloboda i prava za sve građane u Bosni i Hercegovini na njenoj cijeloj teritoriji bez diskriminacije. 


\section{Zaključak}

Puko održavanje izbora svake druge godine (generalni, lokalni) bez kvalitativne reforme ustavno-pravnog, odnosno političkog Sistema, Bosnu i Hercegovinu drži u stanju ,elektoralističke zablude”. To se stanje mora promijeniti.

Shodno našim teorijskim i empirijskim rezultatima istraživanja slobodni smo zaključiti da je izbornu reformu, odnosno novi izborni sistem u BiH moguće tražiti na tragu ukupnih europskih i općenito demokratskih dostignuća. $\mathrm{Na}$ prvom mjestu, izbori trebaju osigurati proporcionalnost broja dobijenih glasova birača s brojem mjesta svake političke opcije u političkom predstavničkom tijelu. $\mathrm{Na}$ taj način se ostvaruje ravnopravnost i politička jednakost građana-birača. Proporcionalni sistem ili, pak, njegovo kombiniranje sa većinskim sistemom omogućava i društvenu i parlamentarnu ravnotežu, osigurava neophodni balans između etničkog i građanskog političkog predstavništva, štiti i utvrđuje legitimitet i legalitet izabranih predstavnika.

Iz dosadašnjeg izlaganja bjelodano je da je za novi iskorak, posebno u vezi za europskim i euroatlantskim integracijama, Bosni i Hercegovini potrebna opsežna ustavna reforma, odnosno bosanskohercegovačkom društvu je neophodna temeljita ustavna i izborna reforma, koja može doći iz tri pravca:

(1) prvo izvršiti neophodne promjena Ustava $\mathrm{BiH}$ i odmah potom Izbornog zakona $\mathrm{BiH}$.

Treba se usvojiti novi građanski Ustav Bosne i Hercegovine. Sadašnji Ustav BiH - Anex IV kao dio Općeg okvirnog sporazuma za mir u Bosni i Hercegovini treba ostati ad acta kao jedna historijska nužnost, koja je u jednom vremenu odigrala važnu historijsku ulogu. Tekst novog Ustava $\mathrm{BiH}$ mora biti plod konsenzusa svih političkih aktera u političkoj areni u $\mathrm{BiH}$.

$\mathrm{Na}$ državnom nivou sastavni dio ustavne reforme mora biti implementacija presuda Europskog suda za ljudska prava iz Strasbourga u slučajevima: Sejdić-Finci; Azra Zornić, Ilijas Pilav, Samir Šlaku i Svetozar Pudarić, kao implementacija svih konačnih i obvezujućih presuda Ustavnog suda u $\mathrm{BiH}$ (U-23/14 „Ljubićc“, U-14/12 „Komšić“ itd.).

Vladajuće etno-nacionalne političke elite se bore za održanje statusa-quo što državu $\mathrm{BiH}$ i bh. društvo drži u stanju ,,permanentne privremenosti“. $\mathrm{Na}$ sceni je sukob dvije političke koncepcije: etno-teritorijalne (Daytonske) koja zagovara ekskluzivni status i primat etničkih grupa tzv. konstitutivnih naroda u političkom predstavljanju, te građanske (strazburško-briselske) koja daje 
primat čl. 25 Međunarodnog pakta o građanskim i političklim pravima, koji je, da paradox bude potpun, sastavni dio Ustava $\mathrm{BiH} .{ }^{31}$

Zato smo izložili novi Model optimalnog akomodacijskog političkog predstavljanja u Bosni i Hercegovini u XXI stoljeću (Arnautović, 2020.1, Arnautović, 2017 : 272-300) koji nudi neophodni balans između etničkog i građanskog političkog predstavljanja.

(2) Drugi pravac je da se odmah ide u političke izmjene Izbornog zakona $\mathrm{BiH}$ bez promjene Ustava $\mathrm{BiH}$.

Ti zahtjevi se obrazlažu potrebom za implementacijom samo jedne odluke Ustavnog suda $\mathrm{BiH}$ (U - 23/14) kako bi se osiguralo ,načelo legitimnog predstavljanja“. Ovaj pristup bi doveo do cementiranja prevaziđenog daytonskog rješenja o ekskluzivnom etno-teritorijalnom predstavljanju tzv. konstitutivnih naroda i za duži period onemogućio donošenje novog modernog građanskog Ustava BiH. Time bi se onemogućila i reforma zasnovana na građanskim principima političkog predstavljanja.

(3) Treći pristup je da se ide na najnužnije „tehničke“ izmjene Izbornog zakona BiH koje bi inter alia obuhvatile reformu imenovanja članova biračkih odbora i izbornih komisija; reformu registracije i identifikacije birača; reformu izbornih jedinica, te reformu glasačkog procesa korištenjem novih tehnologija (uvođenje optičkih skenera, kamera na biračkim mjestima i u Glavnom centru za brojanje i automatsku identifikaciju skeniranjem otisaka prsta tzv. AFIS-a - Automated Fingerprint Identification System). Ovaj pristup bi samo odgodio agoniju ,permanentne privremenosti“ (Arnautović, $\left.2020 .^{1}: 20\right)$. jer ne bi odgovorio na najvažnije pitanje o obrazovanju, karakteru i kriterijima za funkcionalno akomodacijsko političko predstavništvo u Bosni i Hercegovini u XXI stoljeću.

\footnotetext{
${ }^{31}$ Član 25. Međunarodnog pakta o građanskim i političkim pravima glasi: ,, Svaki građanin mora imati pravo i mogućnost da bez ikakvih razlika navedenih u članu 2. i bez neutemeljenih ograničenja: a) sudjeluje u vođenju javnih poslova, direktno ili preko slobodno izabranih predstavnika; b) bira i bude biran na poštenim periodičnim izborima s općim i jednakim pravom glasa koji se moraju provoditi tajnim glasanjem, na način kojim se garantira slobodno izražavanje volje birača; c) ima pristup javnim službama u svojoj zemlji u skladu s načelom opće jednakosti." O tome vidjeti u: Ibrahimagić, Omer, Seizović, Zarije, Arnautović, Suad, 2010., Politički sistem Bosne i Hercegovine Tom I Udžbenik, Promocult, Sarajevo, str. 75. Ovaj Međunarodni pakt je sastavni dio Ustava BiH - Aneks I Dodatni sporazumi o ljudskim pravima koji će se primjenjivati u Bosni i Hercegovini.
} 


\section{Bibliografija}

Almond, G., Verba, S., 1963., The Civic Culture: Political Attitudes and Democracy in Five Nations. Princeton: Princeton University Press,

Arnautović, Suad, 1996., Izbori u Bosni i Hercegovini '90. Analiza izbornog procesa, Promocult, Sarajevo.

Arnautović, Suad, 2009., Političko predstavljanje i izborni sistemi u Bosni i Hercegovini u XX stoljeću, Promocult, Sarajevo,

Arnautović, Suad, 2017., Kontroverze o izborima i izbornom sistemu u Bosni i Hercegovini, Promocult, Sarajevo,

Arnautović, Suad, 2020.1, Model optimalnog akomodacijskog političkog predstavljanja u Bosni i Hercegovini u XXI stoljeću, Podgorica, CIP - Katalogizacija u publikaciji Nacionalna biblioteka Crne Gore, Cetinje, ISBN 978-86-85547-51-5, COBISS.CG-ID 14969860 ,

Arnautović, Suad, 2020., Izborni sistem u BiH je diskriminatoran i proizilazi iz etno-teritorijalnog političkog predstavljanja, https://ba.boell.org/bs/2020/07/28/dosje-mostar-izborni-sistem-u-bih-je-diskriminatoran-proizilazi-iz-etno-teritorijalnog,

Dahl, A. Robert, 1997., Poliarhija participacija i opozicija, Filip Višnjić, Beograd,

Duraković, Nijaz, 2000., Uporedni politički sistemi, Fakultet političkih nauka, Sarajevo,

Ćurak, Nerzuk, 2006., Ideološko-političke podjele u stranačkoj areni Bosne i Hercegovine, u Zborniku: Razvoj političkog pluralizma u Sloveniji i Bosni i Hercegovini, ur. FinkHafner, Danica i Pejanović, Mirko, Ljubljana/Sarajevo,

Hadžiabdić, Irena, 2018., Izbori u Bosni i Hercegovini - Dug put ka demokratskim standardima, Centralna izborna komisija Bosne i Hercegovine, Sarajevo,

Herceg, Nevenko, Tomić, Zoran, 2001., Izbori i izborna kampanja u Bosni i Hercegovini 2000. godine, Sveučilište u Mostaru, Mostar,

Herceg, Nevenko, Tomić, Zoran, 1998., Izbori u Bosni i Hercegovini, Sveučilište u Mostaru, Mostar,

Hrvatska enciklopedija, mrežno izdanje. Leksikografski zavod Miroslav Krleža, 2020.

Huntington, Samuel P., 1991., The Third Wave. Democratization in the Late Twentieth Century, Oklahoma,

Ibrahimagić, Omer, Seizović, Zarije, Arnautović, Suad, 2010., Politički sistem Bosne i Hercegovine Tom I Udžbenik, Promocult, Sarajevo,

Karl, L. Terry, 1986., "Imposing Consent? Electoralism vs. Democratization in El Salvador" In Elections and Democratization in Latin America, 1980-1986., ed. By Paul W. Drake and Eduardo Silva, University of California, San Diego,

Karl, L. Terry, 2000., "Electoralism: Why Elections are not Democracy," in Richard Rose (ed.), The International Encyclopedia of Elections. Congressional Quarterly Books,

Kasapović, Mirjana, 2003., Izborni leksikon, Politička kultura, Zagreb,

Merkel, Wolfgang, Teorije transformacije: demokratska konsolidacija postautoritarnih društava, Politička misao, Vol XXXVI, (1999.), br. 3, str. 121-150,

Mill, John, Stuart, 1989., Izabrani politički spisi Drugi svezak, Informator FPN Zagreb,

Nohlen, Dieter, 1992., Izborno pravo i stranački sustav, Školska knjiga, Zagreb,

Pajvančić, Marijana, 2008, Izborno pravo, drugo izmenjeno i dopunjeno izdanje, Pravni fakultet Novi Sad,

Pejanović, Mirko, 2005., Politički razvitak Bosne i Hercegovine u postdejtonskom periodu, Šahinpašić, Sarajevo, 
Pejanović, Mirko, 2012., Ogledi o državnosti i političkom razvoju Bosne i Hercegovine, Studije, članci, intervjui, Drugo dopunjeno izdanje, Šahinpašić, Sarajevo,

Pejanović, Mirko, Sadiković, Elmir, 2010, Lokalna i regionalna samouprava u Bosni i Hercegovini, Šahinpašić, Sarajevo/Zagreb,

Sartori, Giovanni, 2002., Stranke i stranački sustavi, Politička kultura, Zagreb,

Vujčić, Vladimir, Politička kultura i politička struktura: odnos političke kulture, strukture i demokracije (I.dio), Polit. misao, Vol XXXVI, (1999.), r. 1, str. 113-139.

\title{
Genesis of Electoral Processes in Bosnia and Herzegovina from 1996 to 2018 and Possible Changes in the Constitution and Election Law
}

\begin{abstract}
Summary
We distinguish democratization from stable democracy. In the process of democratization that began in 1990, Bosnia and Herzegovina went through the stages of transition, replacement and displacement of the authoritarian, one-party system into a multi-party system, thus largely discontinuing the ideas (ideology), institutions and procedures of the former regime. However, we still cannot define Bosnia and Herzegovina as a "stable democracy". What are the causes of this condition?

It has been 30 years since the first multi-party elections in Bosnia and Herzegovina. It was the beginning of a process of transition from a one-party to a multi-party political system. From then until the end of 2018, eight presidential election cycles and simultaneous elections for national legislature were held. During that period, numerous political parties of different ideological directions, electoral support and organizational structure were created, but also disappeared from the political arena. Some political parties that were elected to the national parliament in 1990 were "legislative parties" even after the 2018 parliamentary elections, and many of them disappeared from the political arena in the meantime.

The Bosnian electoral system has undergone several significant changes during the transition period. The proportional representation (PR) system for parliamentary elections was introduced in the 1990 elections. In the meantime, there have been structural changes in that system, in all the major elements of that system: (1) in the shaping of constituencies and their magnitude; (2) in the ballot type; (3) in a mathematical formula for transfer of votes into seats. Also, some properties of the majority system (FPTP) were changed for the presidential and mayoral elections? These "technical" changes in the electoral system, while maintaining the outdated exclusive ethno-territorial political representation, reduce the electoral processes in $\mathrm{BiH}$ to mere electoralism. Is there an alternative to such a situation?

Those are the fundamental questions that I set out to answer in this paper.
\end{abstract}

Key words: electoralism, electoral system, party system, constituencies, ballot. 